\title{
IRRIGATION AND FERTILIZATION PROGRAMS FOR "WASHINGTON NAVEL" ORANGE TREES IN SANDY SOIL UNDER DESERT CLIMATIC CONDITIONS. 1- EFFECT ON SOIL PROPERTIES, VEGETATIVE GROWTH AND YIELD
}

\author{
Zayan, M. A. ${ }^{1}$; R. A. Sayed ${ }^{2}$; A. R. El-Shereif ${ }^{1}$ and H. M. A. El- \\ Zawily $^{2}$ \\ ${ }^{1}$ Pomology Department, Faculty of Agriculture, Kafrelsheikh University, \\ Egypt . ${ }^{2}$ Citrus Department, Horticulture Res. Inst., Agric. Res. \\ Center, Giza, Egypt
}

\begin{abstract}
This study was carried out during the two successive growing seasons of 2013 and 2014 on seven years old "Washington Navel" orange trees budded on Volkamer lemon grown at a commercial orchard near ElNubaria city, Beheira Governorate, Egypt, to evaluate the effect of different kinds of fertilizers with using the organic and bio-fertilization partially instead of completed mineral fertilizers as applied at 33.33 to $100 \%$ out of the recommended NPK rate. Organic fertilizers (compost) with three natural rocks (rock phosphate, feldspar and mixed mineral ore) were applied with or without bio-fertilizers (Azospirillum lipoferum for $\mathrm{N}$, Bacillus megaterium for $\mathrm{P}$ and Bacillus circulans for $\mathrm{K}$ ) at $25 \mathrm{~g} /$ tree on soil properties, vegetative growth and fruit yield under three different irrigation levels (1- Actual irrigation practiced in the orchard (control) $100 \%, 2$ - Irrigation at $75 \%$ of control and 3Irrigation at $50 \%$ of control) in sandy soil under drip irrigation system. The results indicated that use of moderate irrigation (2919.34 - 3157.88 $\mathrm{m}^{3} / \mathrm{fed}$./year) and the fertilization program/fed./year $(33.33 \%$ mineral NPK + $33.33 \%$ organic NPK $+33.33 \%$ mixed mineral ore + bio-fertilizer NPK) followed by ( $50 \%$ organic NPK $+50 \%$ mixed mineral ore + bio-fertilizers NPK) exhibited decrease in $\mathrm{pH}$ and increased (EC, O.M., available macronutrients (NPK), soil microorganisms content and dehydrogenase activity) and improve most of vegetative growth parameters particularly trunk cross-sectional area (TCSA), canopy volume (CV), number of shoots, average shoot length, average shoots diameter and number of leaves/shoot at the spring growth cycle, leaf area, leaf dry weight and specific leaf weight in both seasons and achieving the best fruit yield with its components as number of fruits/tree, $\mathrm{kg} / \mathrm{tree}$, ton/fed. and yield efficiency (YE). While the deficit irrigation treatment (level 3) with the same fertilization program resulted in an increase field water use efficiency (FWUE) and water productivity (WP). Therefore, both two programs are recommended for orange farmers to save about $25 \%$ of irrigation water and replaced about $66.66 \%$ of chemical fertilizers by others of natural source and safe for human and environment without any negative responses on soil properties, vegetative growth and yield assuring higher profit for "Washington Navel" orange trees growers under conditions of this study.
\end{abstract}


Keywords: Washington Navel orange, Irrigation levels, Organic fertilizers, Natural rocks, Bio-fertilizers, Soil properties, Vegetative growth, Yield, Water use efficiency, Water productivity

\section{INTRODUCTION}

Citrus consider being one of the most important fruit crops in the world, especially under warm temperate regions, which occupies the third position between fruit crops after grapes and apples. Moreover, citrus is a major fruit crop cultivated in Egypt as its acreage, production and exportation potentialities are concerned. Washington Navel orange is considered the major citrus species in Egypt and has one of the best fruit extractions. Moreover, it is popular fruit in Egypt, because it's nice, low price and nutritive value whereas, the total cultivated area is about 185892 fed., and the fruiting acreage about 157793 fed which produced about 1531952 tons according to Ministry of Agriculture and Land Reclamation (2014). It is well known that $70-80 \%$ of the total water usage worldwide is associated with agriculture especially in arid and semiarid areas of the planet (García-Tejero et al., 2010). Irrigation is one of the most important cultural practices involved in growing citrus in Egypt. The amount of water available under the arid and semi-arid regions as Egypt is the main economic limiting factor to the extension of agriculture especially in the newly reclaimed areas. Within the context of Egyptian horticultural practices the worst is excessive irrigation. The trees receive far too much water than required and the irrigation regime is out phase with the physiological development stage of the tree. Thus, excessive irrigation with far too much nitrogen given at the wrong times causes the trees to cycle into foliar growth flushes when they should be dormant and/or flowering. Rationalizing irrigation water cycles and amount applied will help trees to go dormant during the winter months. Strategy is needed in Egypt to save water by improving water use efficiency (WUE) or water productivity (WP). Using different strategies is a key concept to solve the problem of water scarcity. So nowadays, efforts are being focused on developing not only alternative irrigation methods but also new water management methods in order to reduce water dosages with maintaining maximum tree growth without negative effect on yield and fruit quality (Fereres and Soriano, 2007). Pollution is one of the most important problems affecting human health, especially when the edible part of the plant is polluted with any of pollutants. In this respect, using synthetic chemicals causes the accumulation of harmful residual substances like $\mathrm{NO}_{2}$ and $\mathrm{NO}_{3}$ in the fruit. On the same line, pollution is considered the major problem that faces the exportation process. The question is how to produce more safe fruit for human health avoiding the use of chemicals. Continuous application of natural substances is promising in the long run, 
beside, the high cost of mineral fertilization is a big problem facing citrus growers. Therefore, a great attention was realized to fulfill the nutrient requirements of fruit trees from organic sources as compost with natural rocks and bio fertilizers as an alternative to chemical fertilizers (ElHaddad et al., 1993). Application of organic and bio-fertilizers were considered an important tools to enhance the yield and fruit quality of citrus through increases the organic matter in the soil and also enhances soil physical and chemical properties and biological activities (Shiralipour et al., 1992). The importance of application of natural rocks (rock phosphate, feldspar and mixed mineral ore) may be attributed to their release of macro elements which make converting them in soluble forms. Utilization of these rocks as natural fertilizer has been received significant interest in the recent years since it is natural, inexpensive and available fertilizer (El-Haggar et al., 2004 and Mohamed, 2008). Generally, the main objective of this investigation was to evaluate the effect of different kinds of fertilizers on soil properties, vegetative growth and yield of "Washington Navel" orange trees under drip irrigation system in sandy soil. In particular, this study is an attempt on the hope to rationalize irrigation water and to minimize chemical pollution in the environment.

\section{MATERIALS AND METHODS}

The present investigation was carried out during the two successive growing seasons of 2013 and 2014 on seven years old "Washington Navel" orange trees (Citrus sinensis L., Osbek) budded on Volkamer lemon (Citrus volkameriana L.), planted at $4 \times 6$ meters apart (175 trees/fed.) and grown on a sandy soil at a commercial orchard near El-Nubaria city, Cairo Alexandria desert road, Beheira Governorate, Egypt. The trees were irrigated with Nile water under drip irrigation system and received the same cultural practices as usually done in this area. Soil samples from the experimental site were analyzed before the study began to determine main soil physical and chemical properties (Page et al., 1982). The data representing soil analysis are listed in Tables (1 and 2).

Table (1): Some physical properties and soil moisture constant for the experiment site

\begin{tabular}{|c|c|c|c|c|c|c|c|c|}
\hline $\begin{array}{c}\text { Soil } \\
\text { depth } \\
(\mathrm{cm})\end{array}$ & \multicolumn{2}{|c|}{$\begin{array}{c}\text { Particle size } \\
\text { distribution }\end{array}$} & $\begin{array}{c}\text { Textural } \\
\text { class }\end{array}$ & $\begin{array}{c}\text { Field } \\
\text { capacity } \\
(\%)\end{array}$ & $\begin{array}{c}\text { Wilting } \\
\text { point } \\
(\%)\end{array}$ & $\begin{array}{c}\text { Available } \\
\text { water } \\
(\%)\end{array}$ & $\begin{array}{c}\text { Bulk } \\
\text { density } \\
\left(\mathrm{g} / \mathrm{cm}^{3}\right)\end{array}$ \\
\hline $0-30$ & 91.60 & 2.98 & 5.42 & Sandy & 12.32 & 4.25 & 1.80 & 1.65 \\
$30-60$ & 92.80 & 2.72 & 4.48 & Sandy & 12.10 & 4.21 & 1.60 & 1.66 \\
$60-90$ & 93.18 & 2.94 & 3.88 & Sandy & 11.80 & 4.19 & 1.50 & 1.68 \\
\hline
\end{tabular}


Table (2): Some chemical properties of the experimental soil

\begin{tabular}{|c|c|c|c|c|c|c|c|c|c|c|c|c|c|}
\hline \multirow[t]{2}{*}{$\begin{array}{c}\text { Soil } \\
\text { depth } \\
\text { (cm) }\end{array}$} & \multirow[t]{2}{*}{$\mathrm{pH}$} & \multirow[t]{2}{*}{$\begin{array}{l}\text { EC } \\
(\mathrm{dS} \\
\left.\mathrm{m}^{-1}\right)\end{array}$} & \multirow[t]{2}{*}{$\begin{array}{l}\mathrm{O} . \\
\mathrm{M} . \\
(\%)\end{array}$} & \multicolumn{4}{|c|}{$\begin{array}{l}\text { Soluble cations } \\
\text { (meq/L) }\end{array}$} & \multicolumn{3}{|c|}{$\begin{array}{l}\text { Soluble anions } \\
\text { (meq/L) }\end{array}$} & \multicolumn{3}{|c|}{$\begin{array}{c}\text { Available } \\
\text { macronutrients } \\
\left(\mathrm{mg} \mathrm{kg}^{-1}\right)\end{array}$} \\
\hline & & & & $\underset{+}{\mathrm{Na}}$ & $\underset{++}{\mathrm{Ca}}$ & $\mathrm{Mg}^{+}$ & $\mathrm{K}^{+}$ & $\mathrm{Cl}^{-}$ & $\begin{array}{l}\mathrm{HC} \\
\mathrm{O}_{3}^{-}\end{array}$ & $\mathrm{SO}_{4}$ & $\mathrm{~N}$ & $P$ & $\mathrm{~K}$ \\
\hline $0-30$ & 8.95 & 0.48 & 0.1 & $\begin{array}{l}2 . \\
53\end{array}$ & $\begin{array}{l}1 . \\
45\end{array}$ & $\begin{array}{c}0.6 \\
0\end{array}$ & $\begin{array}{l}0 . \\
18\end{array}$ & $\begin{array}{l}2 . \\
00\end{array}$ & $\begin{array}{c}2.2 \\
3\end{array}$ & $\begin{array}{c}0.5 \\
3\end{array}$ & $\begin{array}{l}18 . \\
25\end{array}$ & $\begin{array}{l}6 . \\
50\end{array}$ & $\begin{array}{l}62 . \\
01\end{array}$ \\
\hline $30-60$ & 8.92 & 0.43 & $\begin{array}{c}0.0 \\
6\end{array}$ & $\begin{array}{l}2 . \\
31\end{array}$ & $\begin{array}{l}1 . \\
27\end{array}$ & $\begin{array}{c}0.5 \\
6\end{array}$ & $\begin{array}{l}0 . \\
15\end{array}$ & $\begin{array}{l}1 . \\
82\end{array}$ & $\begin{array}{c}2.1 \\
0\end{array}$ & $\begin{array}{c}0.3 \\
8\end{array}$ & $\begin{array}{l}17 . \\
20\end{array}$ & $\begin{array}{l}5 . \\
10\end{array}$ & $\begin{array}{l}60 . \\
00\end{array}$ \\
\hline $60-90$ & 8.89 & 0.21 & $\begin{array}{c}0.0 \\
4\end{array}$ & $\begin{array}{l}2 . \\
18\end{array}$ & $\begin{array}{c}1 . \\
15\end{array}$ & $\begin{array}{c}0.4 \\
9\end{array}$ & $\begin{array}{l}0 . \\
11\end{array}$ & $\begin{array}{l}1 . \\
75\end{array}$ & $\begin{array}{c}1.9 \\
7\end{array}$ & $\begin{array}{c}0.2 \\
1\end{array}$ & $\begin{array}{l}15 . \\
85\end{array}$ & $\begin{array}{l}4 . \\
00\end{array}$ & $\begin{array}{l}53 . \\
40\end{array}$ \\
\hline
\end{tabular}

One hundred forty-four trees were selected as uniform as possible in size and vigor. The experiment was designed as split plot in randomized complete blocks as follows:

\section{A. Three irrigation levels were allocated in the main plots as follows: \\ 1- Actual irrigation practiced in the orchard (control) $100 \%$. \\ 2- Irrigation at $75 \%$ of control. \\ 3- Irrigation at $50 \%$ of control.}

The amount of water was controlled through using 16, 12, 8 emitters/tree $(4 \mathrm{~L} / \mathrm{hr})$ at $50 \mathrm{~cm}$ on two lateral lines $100 \mathrm{~cm}$ from the tree trunk each side. The irrigation amount of experiment was calculated by the following equation: Irrigation amount water $=$ Number of drippers $\mathrm{x}$ Discharge of irrigation water (L/hr) x Operating time.

The working hours of irrigation and the quantity of irrigation water applied $\left(\mathrm{m}^{3} /\right.$ tree $)$ in the different irrigation treatments during each growing season were different for spring, summer, autumn and winter as shown in Table (3).

B. Eight fertilization treatments were allocated in subplots (Table 4); the recommended doses of mineral fertilization N, P and K were 140, 40 and 100 units/fed., respectively. Calcium super phosphate $\left(15.5 \% \mathrm{P}_{2} \mathrm{O}_{5}\right)$ was added to the soil on the last week of January in two trenches with depth of $50 \mathrm{~cm}$ and $100 \mathrm{~cm}$ from the trunk at both sides. While, ammonium sulphate $(20.6 \% \mathrm{~N})$ was added at three times at the second week of February, May and August. Meanwhile, potassium sulphate $\left(48 \% \mathrm{~K}_{2} \mathrm{O}\right)$ was added into two equal doses in second week of February and August in both seasons. 
Table (3): Applied water quantity of irrigation water $\left(\mathrm{m}^{3} /\right.$ tree/year) in the different irrigation treatments under drip irrigation system in this experiment in 2013 and 2014 seasons

\begin{tabular}{|c|c|c|c|c|c|c|c|c|}
\hline \multicolumn{9}{|c|}{2013 season } \\
\hline \multirow[b]{2}{*}{ Months } & \multicolumn{2}{|c|}{ Working time/day } & \multicolumn{2}{|c|}{$\begin{array}{c}\text { Level } 1 \text { (Cont.) (24.06) } \\
\mathrm{m}^{3} / \text { tree/year } \\
\end{array}$} & \multicolumn{2}{|c|}{$\begin{array}{c}\text { Level 2(18.05) } \\
\mathrm{m}^{3} / \text { tree/year } \\
\end{array}$} & \multicolumn{2}{|c|}{$\begin{array}{c}\text { Level 3(12.03) } \\
\mathrm{m}^{3} / \text { tree/year }\end{array}$} \\
\hline & Hour & Minute & $\begin{array}{c}\text { Applied } \\
\text { water } \\
\text { liter/hour/ } \\
\text { tree } \\
\end{array}$ & $\begin{array}{c}\text { Total applied } \\
\text { water }\end{array}$ & $\begin{array}{l}\text { Applied water } \\
\text { liter/hour/tree }\end{array}$ & $\begin{array}{c}\text { Total applied } \\
\text { water }\end{array}$ & $\begin{array}{c}\text { Applied } \\
\text { water } \\
\text { liter/hour/ } \\
\text { tree } \\
\end{array}$ & $\left|\begin{array}{c}\text { Total applied } \\
\text { water }\end{array}\right|$ \\
\hline $\begin{array}{l}\text { Spring and autumn } \\
\text { March-April-September- } \\
\text { October }\end{array}$ & 1 & 4.36 & 64 & 8375 & 48 & 6281.5 & 32 & 4187.7 \\
\hline $\begin{array}{c}\text { Summer } \\
\text { May-June-July-August }\end{array}$ & 1 & 20.87 & 64 & 10610 & 48 & 7957.6 & 32 & 5305 \\
\hline $\begin{array}{l}\text { Autumn and winter } \\
\text { November-December- } \\
\text { January-February }\end{array}$ & & 39.65 & 64 & 5075 & 48 & 3806.4 & 32 & 2537.6 \\
\hline Liter/tree/year & & & \multicolumn{2}{|c|}{24060} & \multicolumn{2}{|c|}{18045} & \multicolumn{2}{|c|}{12030} \\
\hline $\mathrm{m}^{3} /$ tree/year & & & & .06 & 18. & & & .03 \\
\hline \multicolumn{9}{|c|}{2014 season } \\
\hline \multirow[b]{2}{*}{ Months } & \multicolumn{2}{|c|}{ Working time/day } & \multicolumn{2}{|c|}{$\begin{array}{c}\text { Level 1 (Cont.) (22.24) } \\
\mathrm{m}^{3} / \text { tree/year }\end{array}$} & \multicolumn{2}{|c|}{$\begin{array}{c}\text { Level 2(16.68) } \\
\mathrm{m}^{3} / \text { tree/year }\end{array}$} & \multicolumn{2}{|c|}{$\begin{array}{c}\text { Level 3(11.12) } \\
\mathrm{m}^{3} / \text { tree/year }\end{array}$} \\
\hline & Hour & Minute & $\begin{array}{c}\text { Applied } \\
\text { water } \\
\text { liter/hour/ } \\
\text { tree }\end{array}$ & $\mid \begin{array}{c}\text { Total applied } \\
\text { water }\end{array}$ & \begin{tabular}{|} 
Applied water \\
liter/hour/tree
\end{tabular} & $\begin{array}{c}\text { Total applied } \\
\text { water }\end{array}$ & $\begin{array}{c}\text { Applied } \\
\text { water } \\
\text { liter/hour/ } \\
\text { tree }\end{array}$ & $\begin{array}{c}\text { Total applied } \\
\text { water }\end{array}$ \\
\hline $\begin{array}{c}\text { Spring and autumn } \\
\text { March-April-September- } \\
\text { October }\end{array}$ & & 59.67 & 64 & 7765 & 48 & 5823.8 & 32 & 3882.5 \\
\hline $\begin{array}{c}\text { Summer } \\
\text { May-June-July-August }\end{array}$ & 1 & 16.18 & 64 & 9995 & 48 & 7496.1 & 32 & 4997.4 \\
\hline $\begin{array}{l}\text { Autumn and winter } \\
\text { November-December- } \\
\text { January-February }\end{array}$ & & 34.96 & 64 & 4475 & 48 & 3356.2 & 32 & 2237.4 \\
\hline Liter/tree/year & & & \multicolumn{2}{|c|}{22235} & \multicolumn{2}{|c|}{16676} & \multicolumn{2}{|c|}{11117} \\
\hline $\mathrm{m}^{3} /$ tree/year & & & \multicolumn{2}{|c|}{22.24} & \multicolumn{2}{|c|}{16.68} & \multicolumn{2}{|c|}{11.12} \\
\hline
\end{tabular}

Table (4): Summary of different kinds of fertilizers treatments

\begin{tabular}{|c|c|}
\hline Fertilization treatments & Quantity (kg/tree/year) \\
\hline $100 \%$ mineral NPK (control) & $\begin{array}{l}3.88 \mathrm{~kg} \text { ammonium sulphate }(20.6 \% \mathrm{~N}), 1.47 \mathrm{~kg} \text { calcium super phosphate }\left(15.5 \% \mathrm{P}_{2} \mathrm{O}_{5}\right) \text { and } \\
1.19 \mathrm{~kg} \text { potassium sulphate }\left(48 \% \mathrm{~K}_{2} \mathrm{O}\right) .\end{array}$ \\
\hline $100 \%$ organic NPK & $\begin{array}{l}57.14 \mathrm{~kg} \text { compost }(1.4 \% \mathrm{~N}), 1.14 \mathrm{~kg} \text { rock phosphate }\left(20 \% \mathrm{P}_{2} \mathrm{O}_{5}\right) \text { and } 6.97 \mathrm{~kg} \text { feldspar }(8.2 \% \\
\left.\mathrm{K}_{2} \mathrm{O}\right) \text {. }\end{array}$ \\
\hline $\begin{array}{l}100 \% \text { organic NPK + bio- } \\
\text { fertilizer NPK }\end{array}$ & $57.14 \mathrm{~kg}$ compost $(1.4 \% \mathrm{~N}), 1.14 \mathrm{~kg}$ rock phosphate, $6.97 \mathrm{~kg}$ feldspar and $25 \mathrm{~g}$ bio-fertilizer. \\
\hline $100 \%$ mixed mineral ore & $5 \mathrm{~kg}$ mixed mineral ore, $3.71 \mathrm{~kg}$ ammonium sulphate, $28.57 \mathrm{~kg}$ compost and $4.57 \mathrm{~kg}$ feldspar. \\
\hline $\begin{array}{l}50 \% \text { mineral NPK }+50 \% \\
\text { organic NPK }\end{array}$ & $\begin{array}{l}1.94 \mathrm{~kg} \text { ammonium sulphate, } 0.740 \mathrm{~kg} \text { calcium super phosphate and } 0.600 \mathrm{~kg} \text { potassium } \\
\text { sulphate }+50 \% \text { of the previous organic recommended fertilizers } 28.57 \mathrm{~kg} \text { compost, } 0.570 \mathrm{~kg} \\
\text { rock phosphate and } 3.49 \mathrm{~kg} \text { feldspar. }\end{array}$ \\
\hline $\begin{array}{l}50 \% \text { organic NPK }+50 \% \\
\text { mixed mineral ore }\end{array}$ & $\begin{array}{l}28.57 \mathrm{~kg} \text { compost, } 0.570 \mathrm{~kg} \text { rock phosphate and } 3.49 \mathrm{~kg} \text { feldspar }+50 \% \text { of the previous mixed } \\
\text { mineral ore recommended fertilizers } 2.5 \mathrm{~kg} \text { mixed mineral ore, } 1.86 \mathrm{~kg} \text { ammonium sulphate, } \\
14.29 \mathrm{~kg} \text { compost and } 2.29 \mathrm{~kg} \text { feldspar. }\end{array}$ \\
\hline $\begin{array}{l}50 \% \text { organic NPK }+50 \% \\
\text { mixed mineral ore }+ \text { bio- } \\
\text { fertilizers NPK }\end{array}$ & $\begin{array}{l}28.57 \mathrm{~kg} \text { compost, } 0.570 \mathrm{~kg} \text { rock phosphate and } 3.49 \mathrm{~kg} \text { feldspar }+50 \% \text { of the previous mixed } \\
\text { mineral ore recommended fertilizers } 2.5 \mathrm{~kg} \text { mixed mineral ore, } 1.86 \mathrm{~kg} \text { ammonium sulphate, } \\
14.29 \mathrm{~kg} \text { compost, } 2.29 \mathrm{~kg} \text { feldspar and } 25 \mathrm{~g} \text { bio-fertilizer. }\end{array}$ \\
\hline $\begin{array}{l}33.33 \% \text { mineral NPK }+33.33 \% \\
\text { organic NPK }+33.33 \% \text { mixed } \\
\text { mineral ore }+ \text { bio-fertilizer NPK }\end{array}$ & $\begin{array}{l}1.29 \mathrm{~kg} \text { ammonium sulphate, } 0.490 \mathrm{~kg} \text { calcium super phosphate and } 0.400 \mathrm{~kg} \text { potassium } \\
\text { sulphate }+19.05 \mathrm{~kg} \text { compost, } 0.380 \mathrm{~kg} \text { rock phosphate and } 2.32 \mathrm{~kg} \text { feldspar }+1.67 \mathrm{~kg} \text { mixed } \\
\text { mineral ore, } 1.24 \mathrm{~kg} \text { ammonium sulphate, } 9.52 \mathrm{~kg} \text { compost and } 1.52 \mathrm{~kg} \text { feldspar }+25 \mathrm{~g} \text { bio- } \\
\text { fertilizer. }\end{array}$ \\
\hline
\end{tabular}

The organic source of NPK namely compost AL-Wadi $(1.4 \% \mathrm{~N})$ was obtained from Delta Bio Tec. Company as present in Table (5). In addition, natural rock phosphate that used in this work contained $(20 \%$ 
$\left.\mathrm{P}_{2} \mathrm{O}_{5}\right)$; feldspar natural rock contained $\left(8.2 \% \mathrm{~K}_{2} \mathrm{O}\right)$ and mixed mineral ore as present in Table (6). They were applied in this form of finely (100-mesh) ground nature product were obtained from Al-Ahram for Mining Company. Bio-fertilizers namely (Azospirillum lipoferum) for $\mathrm{N}$, (Bacillus megaterium) for $\mathrm{P}$ and (Bacillus circulans) for $\mathrm{K}$. The mixed inoculums contains three types of microorganisms, mainly symbiotic $\mathrm{N}$ fixing bacteria, phosphate-dissolving microorganisms and silicatedissolving bacteria, the counts of these microbial types were $1.3 \times 10^{7}$ cell $/ \mathrm{ml}, 1 \times 10^{8} \mathrm{cell} / \mathrm{ml}$ and $2.1 \times 10^{7} \mathrm{cfu} / \mathrm{ml}$ (colony forming units) per gram peat moss carrier. All bio-fertilizers were kindly supplied from bacteriology Lab., Sakha Agric. Res. Station. Compost, natural rocks and bio-fertilizer were added once at last week of January in two trenches (100 cm length $\times 50 \mathrm{~cm}$ width $\times 50 \mathrm{~cm}$ depth) were on both sides of the tree in both seasons, the compost, natural rocks, mixed mineral ore, bio-fertilizer and part of surface soil were mixed and then irrigated.

Table (5): Physical and chemical properties of EL-Wadi compost

\begin{tabular}{|l|c|}
\hline Properties & Values \\
\hline Humidity (\%) & 24 \\
pH $(1-10)$ extract & 6.6 \\
EC (1-10) (dS/m) & 1.6 \\
Total nitrogen (\%) & 1.4 \\
Organic matter (\%) & 58 \\
Organic carbon (\%) & 52.2 \\
C/N ratio & $18: 1$ \\
Total phosphorus (\%) & 0.6 \\
Total potassium (\%) & 0.79 \\
Fe (ppm) & 630 \\
Zn (ppm) & 40 \\
Mn (ppm) & 107 \\
Cu (ppm) & 30 \\
\hline
\end{tabular}

Table (6): Some components of the tested natural rocks

\begin{tabular}{|c|c|c|c|c|c|c|c|c|c|c|c|c|}
\hline $\begin{array}{c}\text { Component } \\
(\%)\end{array}$ & $\mathrm{SiO}_{2}$ & $\mathrm{TiO}_{2}$ & $\mathrm{AL}_{2} \mathrm{O}_{3}$ & $\mathrm{Fe}_{2} \mathrm{O}_{3}$ & $\mathrm{MnO}$ & $\mathrm{MgO}$ & $\mathrm{CaO}$ & $\mathrm{Na}_{2} \mathrm{O}$ & $\mathrm{K}_{2} \mathrm{O}$ & $\mathrm{P}_{2} \mathrm{O}_{5}$ & $\mathrm{SO}_{3}$ & L.O.I \\
\hline $\begin{array}{c}\text { Rock } \\
\text { phosphate }\end{array}$ & 12.75 & 0.02 & 0.35 & 1.12 & 0.07 & 0.61 & 44.12 & 1.12 & 0.05 & 20.00 & 1.98 & 13.62 \\
\hline $\begin{array}{c}\text { Feldspar } \\
\text { Mixed } \\
\text { mineral ore }\end{array}$ & 70.56 & 0.02 & 16.23 & 0.17 & 0.02 & 0.05 & 0.26 & 3.69 & 8.20 & 0.03 & - & 0.37 \\
\hline
\end{tabular}

Twenty four combination treatments ( 3 irrigation treatments $\times 8$ fertilization treatments), each treatment was represented by three replicate, two trees/replicate. During the growing season for each year, the following measurements and determination were carried out.

1. Soil properties: At the end of experiment $\left(15^{\text {th }}\right.$ December, 2014) soil samples for all treatments were collected at two depths 0-30 
and $30-60 \mathrm{~cm}$ and the data was expressed as average to measure some soil properties as $\mathrm{pH}$ and EC, organic matter \% and determine some chemical analysis, i.e total nitrogen using Kjeldahl method, phosphorus and potassium were determined according to Page et al. (1982). Also, microorganisms were calculated as number of colonies/gram soil according to Saleh (2002) and dehydrogenase activity ( $\mathrm{mg} \mathrm{g}^{-1}$ dry soil/96h) was estimated according to Tabatabai (1982).

2. Vegetative growth parameters: Average number of shoots, shoot length, shoot diameter and number of leaves were calculated at the spring growth cycles. Also, the trunk cross-sectional area (TCSA) was calculated by using formula (TCSA $=\mathrm{Girth}^{2} / 4 \pi$ ) given by Kumar et al. (2008), tree canopy volume (CV) was calculated according to the following equation: $\mathrm{CV}=0.528 \times \mathrm{H} \times \mathrm{D}^{2}$. Whereas, $\mathrm{H}=$ tree height, $\mathrm{D}=$ tree diameter (Castle, 1983). However, leaf area $\left(\mathrm{cm}^{2}\right)$ was estimated using formula: Leaf area $=2 / 3 \times$ length $x$ width reported by Chou (1966), leaf dry weight and specific leaf weight $\left(\mathrm{mg} / \mathrm{cm}^{2}\right)$ was calculated according to Ferre and Forshey (1988) as follows: Specific leaf weight $(\mathrm{SLW})=\frac{\text { Leaf dry weight }(\mathrm{mg})}{\text { Leaf area }\left(\mathrm{cm}^{2}\right)}$

3. Yield components: Fruits were harvested at December $15^{\text {th }}$ and December $14^{\text {th }}$ in 2013 and 2014 seasons, respectively and counted, weighted and then the average yield of fruits as $\mathrm{kg} /$ tree, ton/fed. were calculated.

4. Yield efficiency (YE): it was estimated as fruit weight $(\mathrm{kg}) / \mathrm{cm}^{2}$ of trunk cross-sectional area (TCSA).

5. Field water use efficiency (FWUE): It was calculated according to Michael (1978) by the following equation: FWUE $\left(\mathrm{kg} / \mathrm{m}^{3}\right)=\frac{\text { Yield }(\mathrm{kg} / \mathrm{fed} .)}{\text { Water applied }\left(\mathrm{m}^{3} / \mathrm{fed} \text {. }\right)}$

6. Water productivity $\left(\mathrm{L} . \mathrm{E} / \mathrm{m}^{3}\right)$ : It was calculated as the economic return divided by the amount of water applied to the tree (Fereres and Soriano, 2007).

\section{Statistical analysis:}

All the obtained data during both seasons of study were tabulated and statistically analyzed using L.S.D test at $5 \%$ and $1 \%$ level for comparing between different treatment means according to Snedecor and Cochran (1990). All statistical analysis was performed using analysis of variance technique by means of "M-STAT" computer software package. 


\section{Soil properties:}

\section{RESULTS AND DISCUSSIONS}

\section{Soil pH, EC ( $\left.\mathrm{dS} \mathrm{m}^{-1}\right)$ and organic matter (O.M. \%):}

The data obtained in Table (7) showed that there were significant differences among the irrigation levels. The irrigation treatment at level 3 increased soil $\mathrm{pH}$ and $\mathrm{EC}$ values followed by level 2 compared to the lowest values recorded for irrigation at level 1 . This may be attributed to the gradual salt accumulation in the soil profile due to decrease of water and lack of leaching (Omar 1998). These results are in harmony with those obtained by El-Henaway (2006) who found that the moderate level of irrigation of $75 \% \mathrm{ET}$ reduced $\mathrm{pH}$ of soil compared with other levels of 50 and $100 \%$ Et. Also, El-Koumy (2012) reported that increasing irrigation regime reduces $\mathrm{EC}$ and $\mathrm{pH}$ values. The irrigation at level 2 had significantly higher effect on soil organic matter \% than those supplied with level 1(control) or level 3. In this concern Bhriguvanshi et al. (2012), they reported that the functional relationship between soil moisture and organic carbon were statistically significant under drip irrigation. As for the effect of different kinds of fertilizers, the data showed that all fertilization treatments decrease $\mathrm{pH}$ values. The highest $\mathrm{pH}$ values were obtained by the control $\left(T_{1}\right)$ compared with the lowest value recorded for $T_{8}$. However, the highest $E C$ and soil organic matter \% content values obtained by $T_{8}$ compared to control $\left(T_{1}\right)$ which gave the lowest values. These results are in agreement with those obtained by Atom (2013) and Abed El-Hamied (2014) who found that the fertilized citrus tree grown in sandy soil with organic and bio-fertilization improved soil properties compared to conventional fertilizers. In addition, Shukla et al. (2014) and Trinchera et al. (2015) found that combination fertilizers such as organic, bio and natural rocks fertilizers increased soil organic matter content.

Table (7): Effect of three irrigation levels, different kinds of fertilizers and their interaction on soil $\mathrm{pH}, \mathrm{EC}$ and organic matter (\%) content at the end of experiment

\begin{tabular}{|c|c|c|c|c|c|c|c|c|c|c|c|c|}
\hline \multirow{3}{*}{ 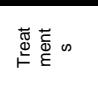 } & \multicolumn{4}{|c|}{$\mathrm{pH}$} & \multicolumn{4}{|c|}{$\mathrm{EC}(\mathrm{dS} / \mathrm{m})$} & \multicolumn{4}{|c|}{ Organic matter (\%) } \\
\hline & \multicolumn{3}{|c|}{ Irrigation levels (m3/tree/year) } & \multirow[b]{2}{*}{$\begin{array}{c}\mathrm{F}- \\
\text { mean }\end{array}$} & \multicolumn{3}{|c|}{ Irrigation levels (m3/tree/year) } & \multirow[b]{2}{*}{$\underset{\text { mean }}{\mathrm{F}-}$} & \multicolumn{3}{|c|}{ Irrigation levels (m3/tree/year) } & \multirow[b]{2}{*}{$\begin{array}{c}\mathrm{F}- \\
\text { mean }\end{array}$} \\
\hline & $\begin{array}{c}\text { Level 1 } \\
23.15 \mathrm{~m}^{3^{*}}\end{array}$ & \begin{tabular}{c|} 
Level 2 \\
$17.36 \mathrm{~m}^{3^{*}}$
\end{tabular} & $\begin{array}{c}\text { Level 3 } \\
11.57 \mathrm{~m}^{3^{*}}\end{array}$ & & $\begin{array}{c}\text { Level } 1 \\
23.15 \mathrm{~m}^{3^{*}}\end{array}$ & $\begin{array}{c}\text { Level } 2 \\
17.36 \mathrm{~m}^{3}\end{array}$ & $\begin{array}{l}\text { Level 3 } \\
11.57 \mathrm{~m}^{3^{*}}\end{array}$ & & $\begin{array}{l}\text { Level 1 } \\
23.15 \mathrm{~m}^{3^{*}}\end{array}$ & $\begin{array}{c}\text { Level 2 } \\
17.36 \mathrm{~m}^{3}\end{array}$ & $\begin{array}{l}\text { Level 3 } \\
11.57 \mathrm{~m}^{3^{*}}\end{array}$ & \\
\hline$\overline{T_{1}}$ & 8.44 & 8.57 & 8.70 & 8.57 & 0.46 & 0.53 & 0.54 & 0.51 & 0.28 & 0.32 & 0.21 & 0.27 \\
\hline $\mathrm{T}_{2}$ & 8.28 & 8.32 & 8.49 & 8.36 & 0.48 & 0.52 & 0.56 & 0.52 & 0.57 & 0.60 & 0.53 & 0.57 \\
\hline$T_{3}$ & 8.21 & 8.23 & 8.34 & 8.26 & 0.49 & 0.54 & 0.55 & 0.53 & 0.61 & 0.67 & 0.58 & 0.62 \\
\hline$T_{4}$ & 8.31 & 8.37 & 8.46 & 8.38 & 0.54 & 0.55 & 0.59 & 0.56 & 0.50 & 0.55 & 0.46 & 0.50 \\
\hline$T_{5}$ & 8.30 & 8.43 & 8.53 & 8.42 & 0.51 & 0.54 & 0.56 & 0.54 & 0.43 & 0.47 & 0.40 & 0.43 \\
\hline $\mathrm{T}_{6}$ & 8.08 & 8.13 & 8.18 & 8.13 & 0.53 & 0.55 & 0.56 & 0.55 & 0.65 & 0.68 & 0.61 & 0.64 \\
\hline $\mathrm{T}_{7}$ & 8.01 & 8.03 & 8.13 & 8.06 & 0.54 & 0.55 & 0.58 & 0.55 & 0.68 & 0.70 & 0.64 & 0.67 \\
\hline$T_{8}$ & 7.92 & 8.01 & 8.06 & 8.00 & 0.55 & 0.58 & 0.59 & 0.57 & 0.74 & 0.83 & 0.70 & 0.76 \\
\hline I-mean & 8.19 & 8.26 & 8.36 & 8.27 & 0.51 & 0.54 & 0.57 & 0.54 & 0.56 & 0.60 & 0.52 & 0.56 \\
\hline LSD at 5\% & $\mathrm{l}=0.025$ & $\mathrm{~F}=0.0$ & $\mathrm{IXF}=$ & 0.052 & $\mathrm{I}=0.014$ & $F=0.0$ & $\mathrm{IXF}=$ & 0.074 & $l=0.025$ & $F=0.0$ & $1 X F=$ & .052 \\
\hline LSD at $1 \%$ & $\mathrm{l}=0.042$ & $\mathrm{~F}=0.0$ & $40 \quad \mathrm{IXF}=$ & 0.070 & $\mathrm{l}=0.023$ & $F=0.0$ & $\mathrm{IXF}=$ & 099 & $l=0.042$ & $F=0.0$ & IXF= & .070 \\
\hline
\end{tabular}

${ }^{*}$ Mean amount of irrigation in both seasons

$\mathrm{T}_{1}=100 \%$ Mineral NPK (control)

$\mathrm{T}_{3}=100 \%$ Organic NPK + Bio-fertilizer NPK

$\mathrm{T}_{5}=50 \%$ Mineral NPK $+50 \%$ Organic NPK

$\mathrm{T}_{2}=100 \%$ Organic NPK

$\mathrm{T}_{4}=100 \%$ Mixed mineral ore

mineral ore

$\mathrm{T}_{6}=50 \%$ Organic NPK $+50 \%$ Mixed

$\mathrm{T}_{7}=50 \%$ Organic NPK $+50 \%$ Mixed mineral ore + Bio-fertilizers NPK 
$\mathrm{T}_{8}=33.33 \%$ Mineral NPK $+33.33 \%$ Organic NPK $+33.33 \%$ Mixed mineral ore + Bio-fertilizer NPK

Concerning the effect of the interaction, data showed that, the differences between treatments were statistically significant. The highest $\mathrm{pH}$ value came from (irrigation at level $3 \times T_{1}$ ), while (irrigation at level $1 \times T_{8}$ ) gave the least value. While, the highest EC value obtained by (irrigation at level $3 \times T_{4}$ ) comparing with the least value obtained by (irrigation at level $1 \times$ $T_{1}$ ) treatment. The highest soil organic matter \% came from (irrigation at level $2 \times T_{8}$ ), whereas the lowest value belonged to (irrigation at level $3 \times$ $\mathrm{T}_{1}$ ) treatment.

\section{Available macronutrients $(\mathrm{mg} / \mathrm{kg})$ :}

Data presented in Table (8) showed that the soil available macronutrients ( $\mathrm{N}, \mathrm{P}$ and $\mathrm{K}$ ) content were significantly increased under irrigation at level 2 followed in decreasing order by the irrigation at level 1 (control) and finally irrigation at level 3 . These results are in conjunction with those obtained by Panigrahi et al. (2014) and Shirgure et al. (2014) on soil cultivated with mandarin trees. They found that the available soil nutrient status (NPK) was increased under the treatment irrigation schedule with $80 \%$ pan evaporation compared with irrigation treatment $100 \%$ (control). Data concerning the effect of different kind of fertilizers, it is clear that the highest $\mathrm{N}, \mathrm{P}$ and $\mathrm{K}$ values were obtained by $\mathrm{T}_{8}$ followed by $T_{7}$ compared to the lowest values obtained from control treatment $\left(T_{1}\right)$. The positive effect of different fertilizers $\left(T_{8}\right)$ on $\mathrm{N}, \mathrm{P}$ and $\mathrm{K}$ content might be attributed to improving soil $\mathrm{pH}$ and organic matter content (Table 7) and to slow release of nutrients from the compost, natural rocks and biofertilizers. These conclusions find support in the results of El-Wakeel et al. (2013) on a clay loamy soil planted with Navel orange trees and Abed El-Hamied (2014) on sandy soil planted with Clementine mandarin trees.

Table (8): Effect of three irrigation levels, different kinds of fertilizers and their interaction on soil total nitrogen, phosphorus and potassium content at the end of experiment

\begin{tabular}{|c|c|c|c|c|c|c|c|c|c|c|c|c|}
\hline \multirow{3}{*}{ 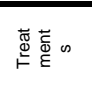 } & \multirow{2}{*}{\multicolumn{4}{|c|}{$\mathrm{N}(\mathrm{mg} / \mathrm{kg})$}} & \multirow{2}{*}{\multicolumn{4}{|c|}{$\mathrm{P}(\mathrm{mg} / \mathrm{kg})$}} & \multicolumn{4}{|c|}{$\mathrm{K}(\mathrm{mg} / \mathrm{kg})$} \\
\hline & & & & \multirow[b]{2}{*}{$\begin{array}{c}F- \\
\text { mean }\end{array}$} & & & & \multirow[b]{2}{*}{$\begin{array}{c}\mathrm{F}- \\
\text { mean }\end{array}$} & \multicolumn{3}{|c|}{ Irrigation levels ( $\mathrm{m}^{3} /$ tree/year) } & \multirow[b]{2}{*}{$\begin{array}{c}\mathrm{F}- \\
\text { mean }\end{array}$} \\
\hline & \begin{tabular}{|c|} 
Level 1 \\
$23.15 \mathrm{~m}^{3^{*}}$
\end{tabular} & \begin{tabular}{c|} 
Level 2 \\
$17.36 \mathrm{~m}^{3^{*}}$
\end{tabular} & $\begin{array}{l}\text { Level } 3 \\
11.57 \mathrm{~m}^{3^{*}}\end{array}$ & & $\begin{array}{l}\text { Level 1 } \\
23.15 \mathrm{~m}^{3}\end{array}$ & $\begin{array}{c}\text { Level 2 } \\
17.36 \mathrm{~m}^{3}\end{array}$ & $\begin{array}{c}\text { Level 3 } \\
11.57 \mathrm{~m}^{3^{*}}\end{array}$ & & $\begin{array}{l}\text { Level } 1 \\
23.15 \mathrm{~m}^{3^{*}}\end{array}$ & $\begin{array}{c}\text { Level 2 } \\
17.36 \mathrm{~m}^{3}\end{array}$ & $\begin{array}{l}\text { Level 3 } \\
11.57 \mathrm{~m}^{3^{*}}\end{array}$ & \\
\hline $\mathrm{T}_{1}$ & 17.43 & 19.69 & 14.67 & 17.26 & 9.41 & 10.66 & 6.70 & 8.92 & 88.26 & 95.08 & 81.63 & 88.32 \\
\hline $\mathrm{T}_{2}$ & 42.90 & 44.53 & 37.63 & 41.69 & 14.95 & 16.55 & 11.92 & 14.47 & 117.68 & 126.22 & 113.52 & 119.14 \\
\hline$T_{3}$ & 44.51 & 46.47 & 40.20 & 43.72 & 15.88 & 17.34 & 12.68 & 15.30 & 124.39 & 131.14 & 116.60 & 124.04 \\
\hline $\mathrm{T}_{4}$ & 42.06 & 43.21 & 36.24 & 40.50 & 13.45 & 15.14 & 9.21 & 12.60 & 100.64 & 110.11 & 92.11 & 100.95 \\
\hline$T_{5}$ & 39.07 & 41.13 & 33.38 & 37.86 & 12.74 & 14.04 & 8.07 & 11.61 & 90.50 & 99.27 & 86.09 & 91.95 \\
\hline$T_{6}$ & 46.57 & 51.25 & 44.81 & 47.54 & 16.45 & 18.31 & 12.92 & 15.89 & 177.90 & 185.14 & 135.04 & 166.03 \\
\hline $\mathrm{T}_{7}$ & 58.33 & 60.99 & 55.03 & 58.11 & 17.79 & 20.28 & 14.47 & 17.51 & 183.00 & 189.12 & 178.25 & 183.45 \\
\hline$T_{8}$ & 62.78 & 67.47 & 60.48 & 63.57 & 21.37 & 24.45 & 17.64 & 21.15 & 197.93 & 203.03 & 185.92 & 195.62 \\
\hline I-mean & 44.20 & 46.84 & 40.30 & 43.78 & 15.25 & 17.09 & 11.70 & 14.68 & 135.03 & 142.39 & 123.64 & 133.69 \\
\hline LSD at $5 \%$ & $\mathrm{l}=0.365$ & $\mathrm{~F}=0.455$ & $5 \quad I X F=$ & .789 & $l=0.156$ & $\mathrm{~F}=0.48$ & $\mathrm{IXF}=$ & 847 & $\mathrm{I}=1.269$ & $\mathrm{~F}=0$ & $1 \times F=$ & .331 \\
\hline LSD at $1 \%$ & $\mathrm{l}=0.605$ & $F=0.60$ & $9 \quad \mathrm{XF}=$ & .054 & $\mathrm{l}=0.259$ & $F=0.65$ & $\mathrm{XF}=$ & .132 & $\mathrm{l}=2.104$ & $F=1$. & IXF & .779 \\
\hline
\end{tabular}

* Mean amount of irrigation in both seasons

$\mathrm{T}_{1}=100 \%$ Mineral NPK (control)

$\mathrm{T}_{2}=100 \%$ Organic NPK

$\mathrm{T}_{3}=100 \%$ Organic NPK + Bio-fertilizer NPK

$\mathrm{T}_{4}=100 \%$ Mixed mineral ore 
$\mathrm{T}_{5}=50 \%$ Mineral NPK $+50 \%$ Organic NPK

$\mathrm{T}_{6}=50 \%$ Organic NPK $+50 \%$ Mixed mineral ore

$\mathrm{T}_{7}=50 \%$ Organic NPK $+50 \%$ Mixed mineral ore + Bio-fertilizers NPK

$\mathrm{T}_{8}=33.33 \%$ Mineral NPK $+33.33 \%$ Organic NPK + 33.33\% Mixed mineral ore + Bio-fertilizer NPK

The interaction was significant and the highest soil available macronutrients $(\mathrm{N}, \mathrm{P}$ and $\mathrm{K})$ values were obtained by (irrigation at level $2 \times T_{8}$ ) compared to the least values recorded by (irrigation at level $3 \times T_{1}$ ) combined treatment.

\section{Soil microorganisms content and dehydrogenase activity:}

The results in Tables (9 and 10) indicated that there were significant differences between all levels of irrigation. Colonies number (fungi, bacteria and yeast) and dehydrogenase activity were increased under irrigation at level 2 and decreased under irrigation at level 1(control). The obtained results are in agreement with those reported by Pascual et al. (2007) and Wang et al. (2008). They found that water deficit produced an increase of soil microorganism and dehydrogenase activity. Regarding to the effect of different kind of fertilizers, the data revealed that, $T_{8}$ produced the highest values of soil microorganisms and dehydrogenase activity followed by $T_{7}$ as compared to the lowest values obtained by control treatment $\left(T_{1}\right)$.

Table (9): Effect of three irrigation levels, different kinds of fertilizers and their interaction on soil microorganisms (fungi and bacteria) content at the end of experiment

\begin{tabular}{|c|c|c|c|c|c|c|c|c|}
\hline \multirow{3}{*}{ Treatments } & \multicolumn{4}{|c|}{$\begin{array}{c}\text { Bungi } \\
\text { (No. of colonies per g of soil) }\end{array}$} & \multicolumn{4}{c|}{ Bacteria } \\
(No. of colonies per g of soil)
\end{tabular}

${ }^{\star}$ Mean amount of irrigation in both seasons $\mathrm{T}_{1}=100 \%$ Mineral NPK (control)

$\mathrm{T}_{2}=100 \%$ Organic NPK

$\mathrm{T}_{3}=100 \%$ Organic NPK + Bio-fertilizer NPK

$\mathrm{T}_{5}=50 \%$ Mineral NPK $+50 \%$ Organic NPK

$\mathrm{T}_{4}=100 \%$ Mixed mineral ore mineral ore

$\mathrm{T}_{7}=50 \%$ Organic NPK $+50 \%$ Mixed mineral ore + Bio-fertilizers NPK

$\mathrm{T}_{8}=33.33 \%$ Mineral NPK $+33.33 \%$ Organic NPK + 33.33\% Mixed mineral ore + Bio-fertilizer NPK

This may be because of the essential roles of organic and biofertilization on enhancing soil fertility, microflora activity, natural hormones, antioxidants, vitamins B and antibiotics which resulted in enhancing dehydrogenase activity Dahama (1999) and Kannaiyan (2002). The present results are in accordance with those reported by Adak et al. (2014), Singha et al. (2014) and Luo et al. (2015). They found that application of combination fertilizers with organic, natural rocks and bio- 
fertilizers increased the microbial biomass and dehydrogenase activity over the control. With respect to the interaction effect, it is clear that the combined treatment (irrigation at level $2 \times T_{8}$ ) increased soil microorganisms content and the dehydrogenase activity compared to the lowest values resulted under (irrigation at level $1 \times T_{1}$ ) combination treatment (control).

Table (10): Effect of three irrigation levels, different kinds of fertilizers and their interaction on soil microorganisms (yeast) content and dehydrogenase activity at the end of experiment

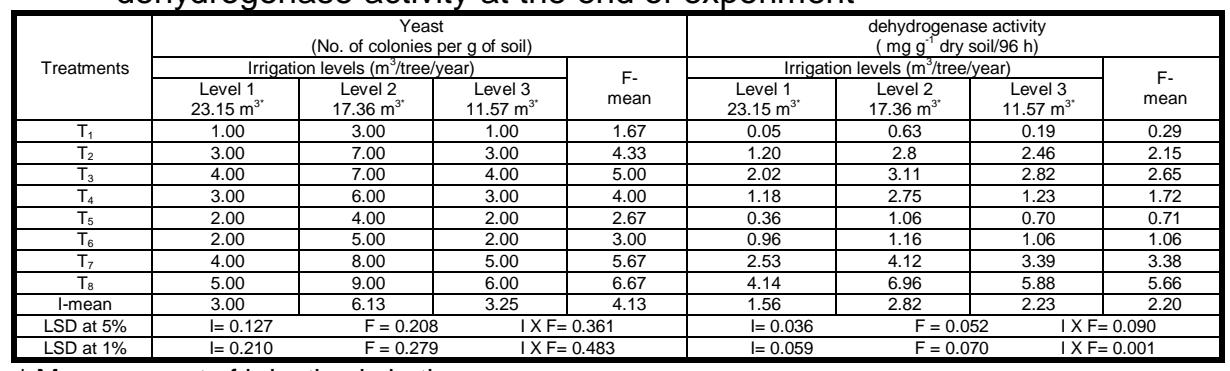

${ }^{*}$ Mean amount of irrigation in both seasons

$\mathrm{T}_{1}=100 \%$ Mineral NPK (control)

$\mathrm{T}_{3}=100 \%$ Organic NPK + Bio-fertilizer NPK

$\mathrm{T}_{5}=50 \%$ Mineral NPK $+50 \%$ Organic NPK

$\mathrm{T}_{2}=100 \%$ Organic NPK

$\mathrm{T}_{4}=100 \%$ Mixed mineral ore

mineral ore

$\mathrm{T}_{7}=50 \%$ Organic NPK $+50 \%$ Mixed mineral ore + Bio-fertilizers NPK

$\mathrm{T}_{8}=33.33 \%$ Mineral NPK $+33.33 \%$ Organic NPK $+33.33 \%$ Mixed mineral ore + Bio-fertilizer NPK

\section{Vegetative growth:}

Trunk cross-sectional area (TCSA) and canopy volume (CV):

Data concerning the specific effect of irrigation levels are presented in Table (11) revealed that trees irrigated at level 2 recorded the highest values of TCSA and CV followed by irrigation at level 1 (control) compared to those trees irrigated at level 3 which registered the lowest values in both seasons. Moreover, there were significant differences among all irrigation treatments. These results are in agreement with those obtained by García Petillo and Castel (2004) on mature Valencia orange and El-Sayed and Ennab (2013) on Valencia orange. They showed that trunk cross-sectional area and tree canopy volume were increased linearly with the amount of water applied. Trees fertilized with $T_{8}$ followed by $T_{7}$ had remarked effect in both parameters than the other ones in both seasons. These results are in line with those obtained by lbe et al. (2011) on sweet orange and Barakat et al. (2012) on Newhall Naval orange, they showed that $45 \mathrm{~kg}$ compost $+600 \mathrm{~g}$ rock phosphate $+3 \mathrm{~kg}$ feldspar $+150 \mathrm{~cm}$ humic acid /tree enhanced trunk circumference and tree canopy volume. As for the interaction treatment the combined treatment (irrigation at level $2 \times T_{8}$ ) tended to increase 
TCSA and CV values compared to the lowest values produced when trees irrigated with level 3 and fertilized by $T_{1}$ in both seasons.

Table (11): Effect of irrigation levels, different kinds of fertilizers and their interaction on trunk cross-sectional area (TCSA), tree canopy volume and number of shoot/branch of spring growth cycle of "Washington Navel" orange trees in 2013 and 2014 seasons

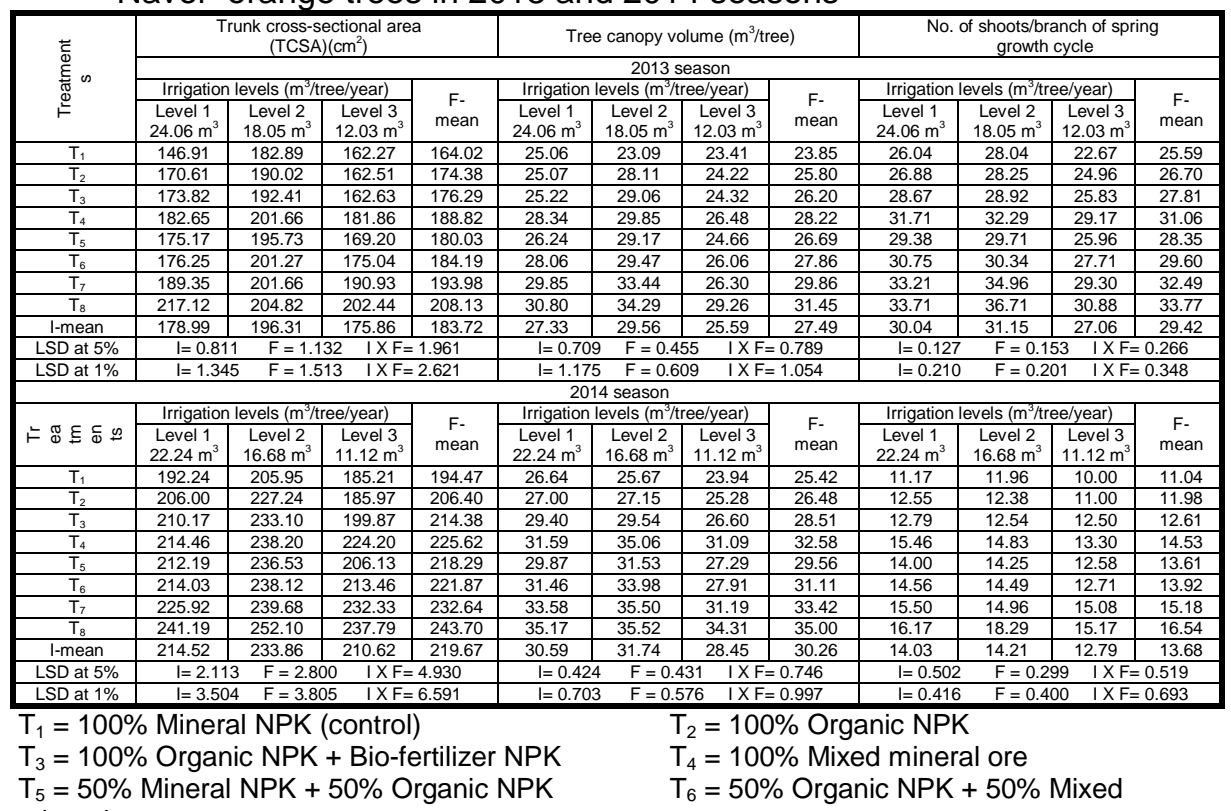
mineral ore

$\mathrm{T}_{7}=50 \%$ Organic NPK $+50 \%$ Mixed mineral ore + Bio-fertilizers NPK

$\mathrm{T}_{8}=33.33 \%$ Mineral NPK $+33.33 \%$ Organic NPK + 33.33\% Mixed mineral ore + Bio-fertilizer NPK

\section{Number of shoots and average shoot length per branch:}

Data presented in Tables (11 and 12) showed that the differences between treatments were statistically significant. The highest number of shoots and average shoot length/branch belonged with the trees irrigated at level 2 followed in decreasing order by the irrigation at level 1 (control) and finally irrigation at level 3 in both seasons. The results are in line with those of Wassel et al. (2007) on Balady mandarin, El-Sayed and Ennab (2013) on Valencia orange and Hussien et al. (2013) on Washington Navel orange. They reported that spring shoot length was increased by raising the amount of irrigation water. Trees fertilized by $T_{8}$ gave the highest number of shoots and shoot length/branch followed by $T_{7}$ and $T_{4}$ compared with the lowest values recorded by $T_{1}$ (control). The favorable influence of compost on growth might be attributed to its effect on supplying the trees with their requirements from various nutrients, reducing soil $\mathrm{pH}$ (Table 7) compared to the data recorded in Table (1), 
also encouraging of microorganisms activity and producing natural auxins (Nijjar, 1985). The great effect of bio-fertilizers on producing natural hormones, antibiotics and Vitamin $\mathrm{B}$ as well as fixation of $\mathrm{N}$ could result in stimulating growth characters (Subba- Rao, 1984). The obtained results are in line with the results of El-Khawaga and Maklad (2013) on Valencia orange and Wassel et al. (2015) on mango trees. The combined treatments (irrigation at level $2 \times T_{8}$ ) tended to increase the number of shoots and shoot length/branch compared to the least values belonged from (irrigation at level $3 \times \mathrm{T}_{1}$ ).

\section{Shoot diameter and number of leaves:}

Data concerning the effect of irrigation levels in Table (12) revealed that trees irrigated at level 2 increased shoot diameter and number of leaves compared with other treatments followed in descending order by irrigation at level 1 and level 3 without significant differences between them. The obtained results are in line with the results of Khalil et al. (2000) on Navel orange, Ahmed et al. (2013) and Ennab and ElSayed (2014) worked on Balady mandarin. They found that the combined fertilizers of organic, bio, rocks as well as chemical fertilizers led to increase shoots diameter and number of leaves/shoot.

Table (12): Effect of irrigation levels, different kinds of fertilizers and their interaction on average shoot length and shoot diameter per branch and number of leaves per shoot of spring growth cycle of "Washington Navel" orange trees in 2013 and 2014 seasons

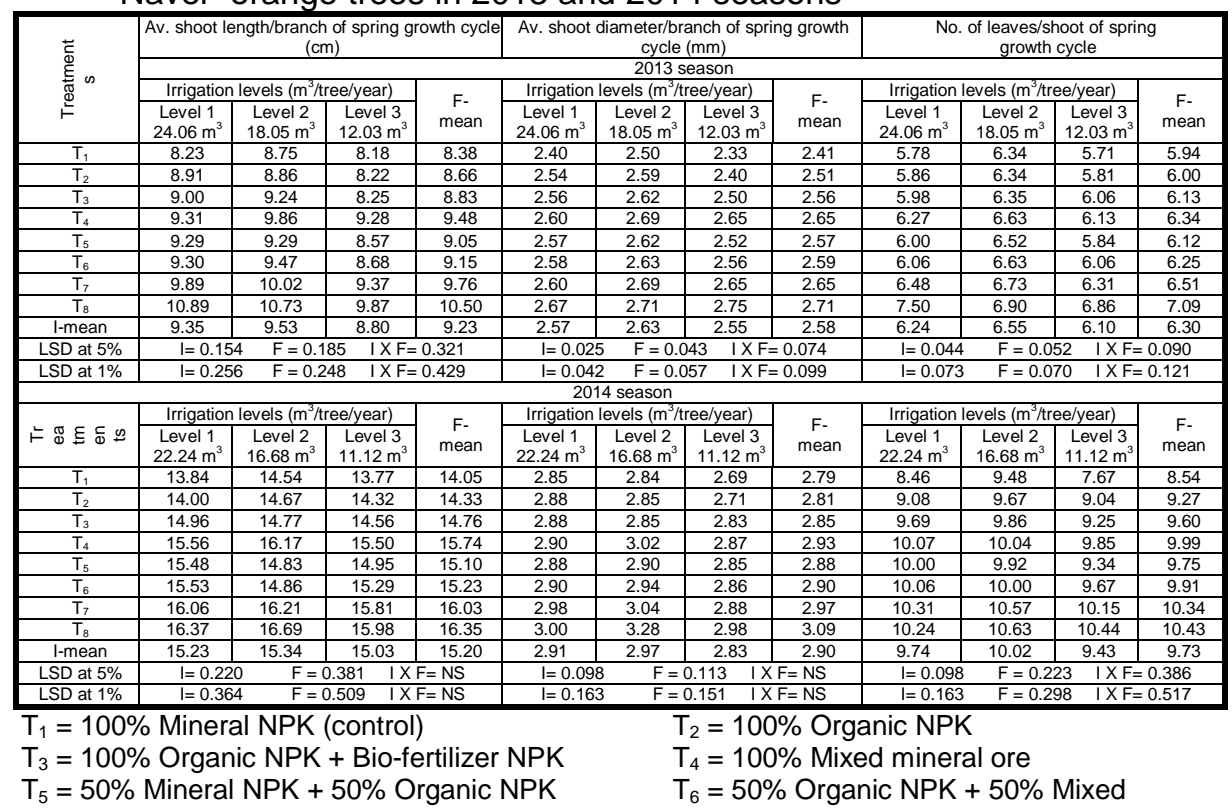

mineral ore 
$\mathrm{T}_{7}=50 \%$ Organic NPK $+50 \%$ Mixed mineral ore + Bio-fertilizers NPK

$\mathrm{T}_{8}=33.33 \%$ Mineral NPK $+33.33 \%$ Organic NPK $+33.33 \%$ Mixed mineral ore + Bio-fertilizer NPK

As for the interaction effect, it is clear that the combined treatment (irrigation at level $3 \times \mathrm{T}_{8}$ ) followed by (irrigation at level $2 \times \mathrm{T}_{8}$ ) and (irrigation at level $2 \times \mathrm{T}_{7}$ ) gave the highest average shoot diameter without significant differences among them in the first season, but in the second one there were no significant differences among all treatments. Conclusively, application of (irrigation at level $1 \times T_{8}$ ) treatment in the first season and (irrigation at level $2 \times \mathrm{T}_{8}$ ) and (irrigation at level $2 \times \mathrm{T}_{7}$ ) combination treatments in the second season gave the highest number of leaves/shoot without significant differences between them compared to (irrigation at level $3 \times \mathrm{T}_{1}$ ) and (irrigation at level $1 \times \mathrm{T}_{1}$ ) combined treatments in both seasons.

\section{Leaf growth parameters:}

Data of Table (13) cleared that the largest leaf area and highest specific leaf weight were recorded with irrigation treatment at level 2, while the least values were obtained with level 3 and level 1 for both parameters, respectively in both seasons. Leaf dry weight was significantly increased under high (level 1) and moderate (level 2) irrigation levels without significant difference between them as compared to low irrigation (level 3 ) in both seasons.

Table (13): Effect of irrigation levels, different kinds of fertilizers and their interaction on leaf growth parameters of "Washington Navel" orange trees in 2013 and 2014 seasons

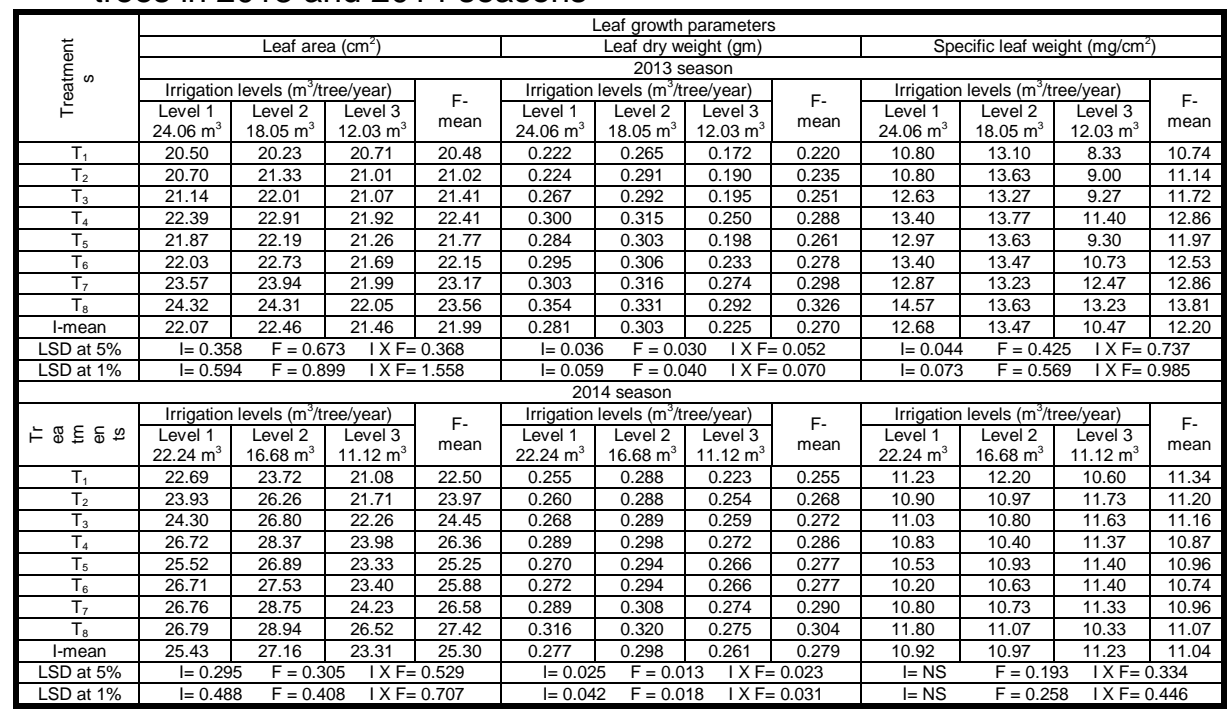

$\mathrm{T}_{1}=100 \%$ Mineral NPK (control)

$\mathrm{T}_{2}=100 \%$ Organic NPK 
$\mathrm{T}_{3}=100 \%$ Organic NPK + Bio-fertilizer NPK

$\mathrm{T}_{5}=50 \%$ Mineral NPK $+50 \%$ Organic NPK mineral ore

$\mathrm{T}_{7}=50 \%$ Organic NPK $+50 \%$ Mixed mineral ore + Bio-fertilizers NPK

$\mathrm{T}_{8}=33.33 \%$ Mineral NPK $+33.33 \%$ Organic NPK $+33.33 \%$ Mixed mineral ore + Bio-fertilizer

NPK

These results are in agreement with those of Balaganvi and Kumathe (2004) on Kagzi Lime, El-Abd (2005) on Washington Navel orange and Fiorella et al. (2015) mature orange trees cv. "Tarocco Meli". They found that there were positive relation between irrigation amounts and leaf area. Concerning the effect of different kinds of fertilizers, the data exhibited that all leaf growth parameters significantly increased under $T_{8}$ compared to control $\left(T_{1}\right)$. These results confirmed with those obtained by Abdel-Hak et al. (2012) on Valencia orange, Barakat et al. (2012) on Newhall Naval orange and Abdelaal et al. (2013) on Valencia orange. As for, the interaction the largest leaf area came from (irrigation at level $1 \times T_{8}$ ), (irrigation at level $2 \times T_{8}$ ) and (irrigation at level $2 \times T_{7}$ ) in the first season and (irrigation at level $2 \times T_{8}$ ), in the second one compared to the lowest values obtained by (irrigation at level $2 \times T_{1}$ ) and (irrigation at level $3 \times T_{1}$ ) in both seasons, respectively. The heaviest leaf dry weight obtained by (irrigation at level $1 \times T_{8}$ ) in the first season and (irrigation at level $2 \times T_{8}$ ) or (irrigation at level $1 \times T_{8}$ ) in the second season without significant difference between them comparing with (irrigation at level $3 \times \mathrm{T}_{1}$ ) which recorded the lowest value in both seasons. The highest value of specific leaf weight belonged to (irrigation at level $1 \times T_{8}$ ) combination treatments compared with (irrigation at level $3 \times T_{1}$ ) in the first season, while in the second one the highest values recorded by (irrigation at level $2 \times \mathrm{T}_{1}$ ) comparing with the least value resulted by (irrigation at level $1 \times \mathrm{T}_{6}$ ) combination treatment.

\section{Yield components:}

Data in Table (14) exhibited that moderate irrigation treatment (level

2) increased number of fruits/tree and yield as $\mathrm{kg} / \mathrm{tree}$ and ton/fed. compared to level 1 (control) and deficit irrigation (level 3) in both seasons. Moreover, there were statistically different within all treatments. The resulted increase in yield as $\mathrm{kg} /$ tree could be attributed to appropriate vegetative growth and improved nutritional status of the irrigated trees. These data are in accordance with those obtained by El Abd (2005) on Navel orange, Wassel et al. (2007) on Balady mandarin, Morgan et al. (2009) on 'Ambersweet' orange, El-Sayed and Ennab (2013) on Valencia orange and Hussien et al. (2013) on Washington Navel orange trees. They found that a gradual reduction in fruit yield was observed as the amount of irrigation water decreased. As for the effect of different kinds of fertilizers, it is clear that, trees treated with $T_{8}$ in the first season and $T_{7}$ or $T_{4}$ 
in the second season significantly increased the total number of fruits/tree without significant differences between them when compared to the lowest fruit number recorded by $T_{3}$ in both seasons. However, trees fertilized with $\mathrm{T}_{8}$ and $\mathrm{T}_{7}$ produced maximum yield as $\mathrm{kg} / \mathrm{tree}$ and ton/fed. meanwhile, the minimum yield obtained with $T_{1}$ (control). The obtained results are in line with those obtained by Mansour and Shaaban (2007) on Washington Navel orange, El-Mohamedy and Ahmed (2009) on Balady mandarin, Abdel-Hak et al. (2012) on Valencia orange, Hegazi et al. (2014) on Flame seedless grapevines and Ibrahim and Maklad (2014) on Washington Navel orange trees. They showed that the highest yield of the trees which fertilized with compost, rock phosphate, feldspar and biofertilizers. The highest number of fruits per trees belonged with the combination treatment (irrigation at level $2 \times T_{8}$ ) or (irrigation at level $2 \times T_{7}$ ) in the first season and (irrigation at level $2 \times T_{7}$ ) or (irrigation at level $2 \times T_{5}$ ) in the second season, whereas (irrigation at level $1 \times T_{3}$ ) combination treatment gave the least number in both seasons. However, the highest yield as $\mathrm{kg} / \mathrm{tree}$ and ton/fed. came from (irrigation at level $2 \times \mathrm{T}_{8}$ ) and (irrigation at level $2 \times \mathrm{T}_{7}$ ) combination treatments in both seasons without significant differences between them, while the lowest yield was always belonged to (irrigation at level $3 \times \mathrm{T}_{1}$ ) treatment in both seasons.

Table (14): Effect of irrigation levels, different kinds of fertilizers and their interaction on yield components of "Washington Navel" orange trees in 2013 and 2014 seasons

\begin{tabular}{|c|c|c|c|c|c|c|c|c|c|c|c|c|}
\hline \multirow{5}{*}{ 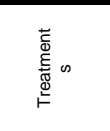 } & \multicolumn{12}{|c|}{ Yield components } \\
\hline & \multicolumn{4}{|c|}{ No. of fruits/tree } & \multicolumn{4}{|c|}{$\mathrm{Kg} /$ tree } & \multicolumn{4}{|c|}{ Ton/fed. } \\
\hline & \multicolumn{12}{|c|}{2013 season } \\
\hline & \multicolumn{3}{|c|}{ Irrigation levels ( $\mathrm{m}^{3} /$ tree/year) } & \multirow[b]{2}{*}{$\begin{array}{c}\mathrm{F}- \\
\text { mean }\end{array}$} & \multicolumn{3}{|c|}{ Irrigation levels ( $\mathrm{m}^{3} /$ tree/year) } & \multirow[b]{2}{*}{$\begin{array}{c}\mathrm{F}- \\
\text { mean }\end{array}$} & \multicolumn{3}{|c|}{ Irrigation levels ( $\mathrm{m}^{3} /$ tree/year) } & \multirow[b]{2}{*}{$\begin{array}{c}\mathrm{F}- \\
\text { mean }\end{array}$} \\
\hline & \begin{tabular}{|c|} 
Level 1 \\
$24.06 \mathrm{~m}^{3}$ \\
\end{tabular} & \begin{tabular}{|c|} 
Level 2 \\
$18.05 \mathrm{~m}^{3}$ \\
\end{tabular} & $\begin{array}{c}\text { Level } 3 \\
12.03 \mathrm{~m}^{3} \\
\end{array}$ & & $\begin{array}{c}\text { Level 1 } \\
24.06 \mathrm{~m}^{3}\end{array}$ & $\begin{array}{c}\text { Level 2 } \\
18.05 \mathrm{~m}^{3} \\
\end{array}$ & $\begin{array}{c}\text { Level } 3 \\
12.03 \mathrm{~m}^{3} \\
\end{array}$ & & \begin{tabular}{c|} 
Level 1 \\
$24.06 \mathrm{~m}^{3}$ \\
\end{tabular} & $\begin{array}{c}\text { Level } 2 \\
18.05 \mathrm{~m}^{3}\end{array}$ & $\begin{array}{c}\text { Level } 3 \\
12.03 \mathrm{~m}^{3}\end{array}$ & \\
\hline $\mathrm{T}_{1}$ & 267.79 & 288.22 & 268.74 & 274.92 & 67.43 & 74.86 & 66.29 & 69.53 & 11.80 & 13.10 & 11.60 & 12.17 \\
\hline $\mathrm{T}_{2}$ & 260.97 & 280.71 & 273.24 & 271.64 & 69.14 & 77.14 & 68.00 & 71.43 & 12.10 & 13.50 & 11.90 & 12.50 \\
\hline$T_{3}$ & 257.67 & 284.42 & 266.23 & 269.44 & 70.86 & 78.29 & 69.15 & 72.77 & 12.40 & 13.70 & 12.10 & 12.73 \\
\hline $\mathrm{T}_{4}$ & 272.64 & 303.87 & 287.72 & 288.08 & 77.14 & 84.86 & 76.86 & 79.62 & 13.50 & 14.85 & 13.45 & 13.93 \\
\hline $\mathrm{T}_{5}$ & 260.42 & 286.73 & 277.22 & 274.79 & 72.57 & 79.71 & 72.17 & 74.82 & 12.70 & 13.95 & 12.63 & 13.09 \\
\hline$T_{6}$ & 266.27 & 294.74 & 279.95 & 280.32 & 74.29 & 82.29 & 73.14 & 76.57 & 13.00 & 14.40 & 12.80 & 13.40 \\
\hline $\mathrm{T}_{7}$ & 275.93 & 325.45 & 287.60 & 296.33 & 78.29 & 91.43 & 77.71 & 82.48 & 13.70 & 16.00 & 13.60 & 14.43 \\
\hline$T_{8}$ & 300.04 & 325.97 & 281.28 & 302.43 & 87.03 & 94.29 & 78.29 & 86.54 & 15.23 & 16.50 & 13.70 & 15.14 \\
\hline I-mean & 270.22 & 298.76 & 277.75 & 282.24 & 74.59 & 82.86 & 72.70 & 76.72 & 13.05 & 14.50 & 12.72 & 13.43 \\
\hline LSD at $5 \%$ & \multirow{2}{*}{$\begin{array}{l}I=5.971 \\
I=9.901\end{array}$} & $\mathrm{~F}=4.3$ & \multirow{2}{*}{\multicolumn{2}{|c|}{$\begin{array}{l}1 X F=7.499 \\
X F=10.03\end{array}$}} & \multirow{2}{*}{$\begin{array}{l}l=1.700 \\
I=2.819\end{array}$} & \multirow{2}{*}{\multicolumn{2}{|c|}{$\begin{array}{l}F=2.127 \\
F=2.844\end{array}$}} & \multirow{2}{*}{$\begin{array}{l}X F=3.684 \\
X F=4.926\end{array}$} & \multirow{2}{*}{$\begin{array}{l}l=0.878 \\
I=1.456\end{array}$} & \multirow{2}{*}{\multicolumn{2}{|c|}{$\begin{array}{l}F=1.165 \\
F=1.558\end{array}$}} & \multirow{2}{*}{$\begin{array}{l}\mathrm{IXF}=2.018 \\
\mathrm{IXF}=2.698\end{array}$} \\
\hline LSD at $1 \%$ & & $F=5.7$ & & & & & & & & & & \\
\hline \multicolumn{13}{|c|}{2014 season } \\
\hline \multirow[b]{2}{*}{ ト®ほ } & \multicolumn{3}{|c|}{ Irrigation levels ( $\mathrm{m}^{3} /$ tree/year) } & \multirow[b]{2}{*}{$\begin{array}{c}\mathrm{F}- \\
\text { mean }\end{array}$} & \multicolumn{3}{|c|}{ Irrigation levels ( $\mathrm{m}^{3} /$ tree/year) } & \multirow[b]{2}{*}{$\begin{array}{c}\mathrm{F}- \\
\text { mean }\end{array}$} & \multicolumn{3}{|c|}{ Irrigation levels ( $\mathrm{m}^{3} /$ tree/year) } & \\
\hline & \begin{tabular}{c|} 
Level 1 \\
$22.24 \mathrm{~m}^{3}$ \\
\end{tabular} & $\begin{array}{c}\text { Level } 2 \\
16.68 \mathrm{~m}^{3}\end{array}$ & $\begin{array}{c}\text { Level } 3 \\
11.12 \mathrm{~m}^{3}\end{array}$ & & \begin{tabular}{c|} 
Level 1 \\
$22.24 \mathrm{~m}^{3}$ \\
\end{tabular} & $\begin{array}{c}\text { Level } 2 \\
16.68 \mathrm{~m}^{3} \\
\end{array}$ & $\begin{array}{c}\text { Level } 3 \\
11.12 \mathrm{~m}^{3} \\
\end{array}$ & & $\begin{array}{c}\text { Level } 1 \\
22.24 \mathrm{~m}^{3}\end{array}$ & $\begin{array}{c}\text { Level } 2 \\
16.68 \mathrm{~m}^{3}\end{array}$ & $\begin{array}{c}\text { Level } 3 \\
11.12 \mathrm{~m}^{3}\end{array}$ & $\begin{array}{l}F- \\
\text { mean }\end{array}$ \\
\hline $\mathrm{T}_{1}$ & 276.75 & 293.06 & 277.17 & 282.33 & 69.71 & 77.14 & 68.00 & 71.62 & 12.20 & 13.50 & 11.90 & 12.53 \\
\hline$T_{2}$ & 263.04 & 292.41 & 257.68 & 271.04 & 70.29 & 78.43 & 69.43 & 72.72 & 12.30 & 13.73 & 12.15 & 12.73 \\
\hline $\mathrm{T}_{3}$ & 255.81 & 292.99 & 260.87 & 269.89 & 70.86 & 79.14 & 70.29 & 73.43 & 12.40 & 13.8 & 12.30 & 12.85 \\
\hline$T_{4}$ & 283.18 & 305.20 & 266.53 & 284.97 & 81.43 & 88.00 & 77.71 & 82.38 & 14.25 & 15.40 & 13.60 & 14.42 \\
\hline$T_{5}$ & 271.21 & 310.38 & 269.50 & 283.70 & 76.00 & 84.00 & 74.86 & 78.29 & 13.30 & 14.70 & 13.10 & 13.70 \\
\hline$T_{6}$ & 275.46 & 300.67 & 274.54 & 283.45 & 77.71 & 84.57 & 76.29 & 79.52 & 13.60 & 14.80 & 13.35 & 13.92 \\
\hline$T_{7}$ & 284.39 & 316.53 & 265.74 & 288.89 & 82.00 & 94.29 & 78.57 & 84.95 & 14.35 & 16.50 & 13.75 & 14.87 \\
\hline$T_{8}$ & 284.59 & 297.95 & 268.14 & 283.56 & 88.00 & 95.71 & 79.43 & 87.71 & 15.40 & 16.75 & 13.90 & 15.35 \\
\hline I-mean & 274.31 & 301.11 & 267.52 & 280.98 & 77.00 & 85.16 & 74.32 & 78.83 & 13.48 & 14.90 & 13.01 & 13.79 \\
\hline LSD at 5\% & $\mathrm{I}=8.213$ & $\mathrm{~F}=4$ & 757 & $\mathrm{X}=8.239$ & $l=2.404$ & $F=1$ & 1.903 & $1 X F=3.296$ & $\mathrm{I}=0.802$ & $F=0$ & .951 & $X F=1.648$ \\
\hline LSD at $1 \%$ & $\mathrm{l}=13.620$ & $\mathrm{~F}=6$ & 359 & $\mathrm{XF}=11.010$ & $\mathrm{I}=3.987$ & $\mathrm{~F}=2$ & 2.544 & $\mathrm{IXF}=4.406$ & $\mathrm{I}=1.329$ & $\mathrm{~F}=1$ & 272 & $\mathrm{IXF}=2.203$ \\
\hline $\begin{array}{l}\mathrm{T}_{1} \\
\mathrm{~T}_{3} \\
\mathrm{~T}_{5}\end{array}$ & $50 \% \mathrm{Mi}$ & $\begin{array}{l}\text { yanic } \\
\text { eral N }\end{array}$ & $\mathrm{PK}+\mathrm{B}$ & $\begin{array}{l}\text { ol) } \\
\text {-fertiliz } \\
\text { Organi }\end{array}$ & $\begin{array}{l}\text { NPK } \\
\text { NPK }\end{array}$ & & $\begin{array}{l}4=100 \\
6=50 \%\end{array}$ & $\begin{array}{l}\text { \% M Mixe } \\
\% \text { Orgar }\end{array}$ & $\begin{array}{l}\text { c NPK } \\
\text { mineral } \\
\mathrm{NPK}+\end{array}$ & $\begin{array}{l}\text { re } \\
0 \% \mathrm{~N}\end{array}$ & & \\
\hline
\end{tabular}
mineral ore

$\mathrm{T}_{7}=50 \%$ Organic NPK $+50 \%$ Mixed mineral ore + Bio-fertilizers NPK 
$\mathrm{T}_{8}=33.33 \%$ Mineral NPK $+33.33 \%$ Organic NPK + 33.33\% Mixed mineral ore + Bio-fertilizer NPK

\section{Yield efficiency (YE):}

Data in Table (15) showed that yield efficiency as $\mathrm{kg} / \mathrm{cm}^{2}$ of TCSA was increased under irrigation at level 1 (control) and level 2 treatments comparing with irrigation at level 3 in both seasons. These results find support with those reported by Pérez-Pérez et al. (2008) on mature "Lan late" sweet orange trees and Ennab and El-Sayed (2014) on Balady mandarin trees. They reported that yield efficiency was decreased under deficit irrigation as compared with control. Data also exhibited that, fertilized trees with $T_{1}, T_{4}$ and $T_{7}$ recorded the highest values of yield efficiency as $\mathrm{kg} / \mathrm{cm}^{2}$ of TCSA without significant differences among them in both season. Yield efficiency as $\mathrm{kg} / \mathrm{cm}^{2}$ of TCSA was significantly affected by the interaction in both seasons. However, (irrigation at level 1 $x T_{1}$ ), (irrigation at level $2 \times T_{7}$ ) and (irrigation at level $2 \times T_{8}$ ) in the first season and (irrigation at level $2 \times \mathrm{T}_{7}$ ) combination treatment in the second season gave the highest values compared to the lowest values obtained by (irrigation at level $1 \times T_{8}$ ) and (irrigation at level $3 \times T_{8}$ ) combination treatments in both season, respectively.

Table (15): Effect of irrigation levels, different kinds of fertilizers and their interaction on yield efficiency, field water use efficiency and water productivity of "Washington Navel" orange trees in 2013 and 2014 seasons

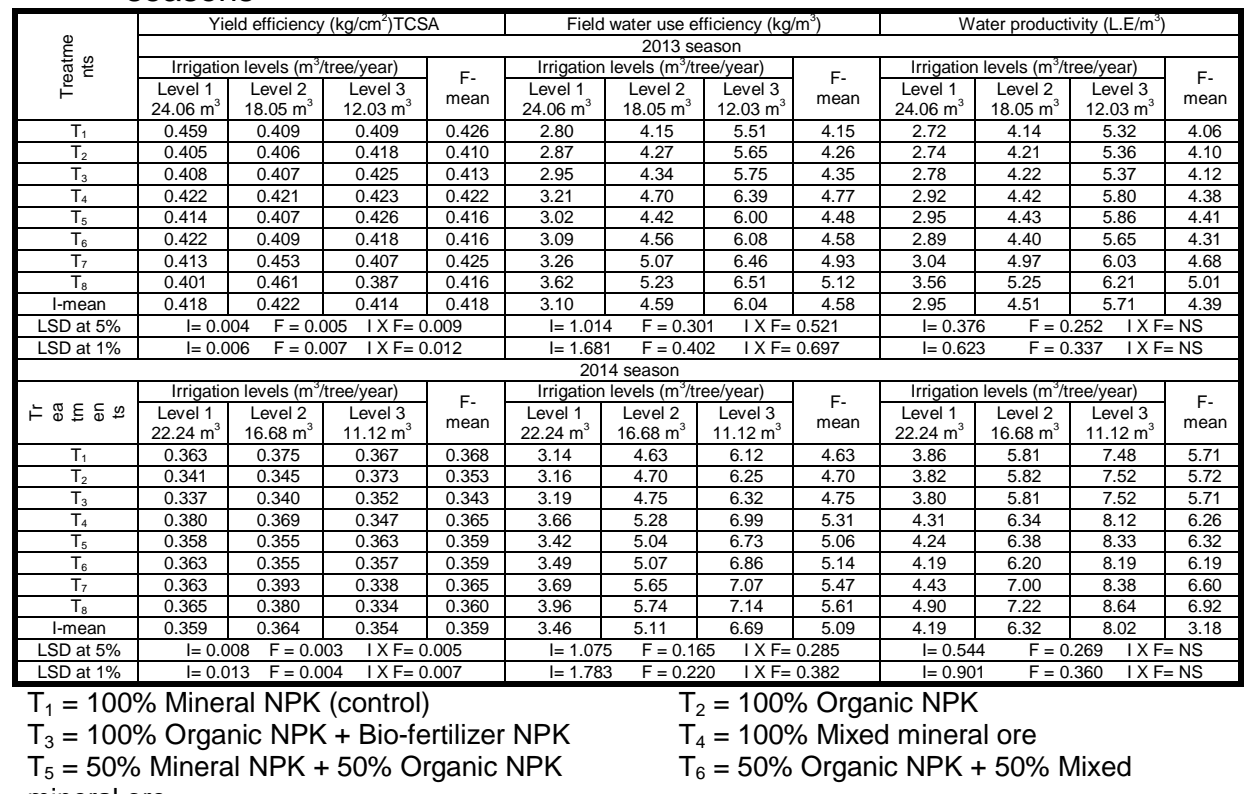
mineral ore

$\mathrm{T}_{7}=50 \%$ Organic NPK $+50 \%$ Mixed mineral ore + Bio-fertilizers NPK 
$\mathrm{T}_{8}=33.33 \%$ Mineral NPK $+33.33 \%$ Organic NPK $+33.33 \%$ Mixed mineral ore + Bio-fertilizer NPK

Field water use efficiency (FWUE) and water productivity (WP):

Data presented in Table (Table 15) revealed that the highest significant values of FWUE and WP were obtained from trees irrigated at level 3 compared to the control which gave the lowest values in both seasons. These results are in agreement with those obtained by GarcíaTejero et al. (2011) on sweet orange, Abo El-Enin (2012) on Washington Navel, Panigrahi et al. (2014) on 'Kinnow' mandarin and Fiorella et al. (2015) on mature orange trees cv. "Tarocco Meli". They all found that the highest FWUE and WP values were resulted from the deficit irrigation treatment (level 3), whereas the lowest values was obtained under control treatment (level 1) due to much applied irrigation water. This value (water productivity) also has an important value for growers by increasing their income by using less amounts of irrigation water. The fertilization treatments $T_{8}$ gave the highest FWUE and WP comparing with control which recorded the lowest values in both seasons. The highest FWUE was estimated for the interaction treatments (irrigation at level $3 \times T_{8}$ ) and (irrigation at level $3 \times T_{5}$ ) in both seasons, respectively comparing with the lowest value recorded for the combination treatments (irrigation at level $1 \times T_{1}$ ) and (irrigation at level $1 \times T_{3}$ ) in both seasons, respectively. There exhibited non-significant differences among all combination treatments as for WP in both seasons.

\section{CONCLUSIONS AND RECOMMENDATION}

From the results obtained, it could be concluded that the moderate irrigation (2919.34 - $3157.88 \mathrm{~m}^{3} / \mathrm{fed}$./year) as appropriate program for "Washington Navel" orange trees in sandy soil. Applying this program (level 2) rationalizing and saved about $25 \%$ of the amount of irrigation water/fed./year without any negative responses on soil properties, vegetative growth and yield. Also, this study introduces another appropriate program for "Washington Navel" orange trees fertilization in sandy soil. This program $\left(T_{8}\right.$ and/or $\left.T_{7}\right)$ replaced about $66.66 \%$ of chemical fertilizers by others of natural source and safe for human and environment with higher profit for growers. Applying both programs (irrigation program $x$ fertilization program) to "Washington Navel" orange trees under conditions of this study is recommended for its positive effects on most soil properties, vegetative growth and yield and producing fruits with less pollution for human and environment. 


\section{REFERENCES}

Abdelaal, A.H.M.; F.F. Ahmed; S.E.M.A. El-Masry and A.A. Abdallah (2013). Using potassium, sulphur as well as organic and biofertilization for alleviating the adverse effects of salinity on growth and fruiting of Valencia orange trees. Stem Cell, 4(4): 2732.

Abdel-Hak R.S.; S. El-Shazly; A. El-Gazzar; E.A. Shaaban and M.S. ElShamma (2012). Response of Valencia orange trees to rockfeldspar applications in reclaimed soils. J. Appl. Sci. Res., 8(7): 3160-3165.

Abed El-Hamied, S.A. (2014). Effect of multi-ingredient of bokashi on productivity of mandarin trees and soil properties under saline water irrigation. IOSR Journal of Agriculture and Veterinary Science, 7(11): 79-87.

Abo El-Enin, M.M.S. (2012). Improvement of Washington navel orange fruit quality using water regimes and $\mathrm{GA}_{3}$, potassium and calcium foliar applications. Ph.D. Thesis, Fac. Agric., Kafrelsheikh Univ., Egypt.

Adak, T.; K. Kumar; A. Singha; S.K. Shukla and V.K. Singh (2014). Assessing soil characteristics and guava orchard productivity as influenced by organic and inorganic substrates. The Journal of Animal \& Plant Sciences, 24(4): 1157-1165.

Ahmed, F.F.; A.M.K. Abdel Aal and M.H. A. Faraag (2013). Partial replacement of inorganic $\mathbf{N}$ fertilizer in Balady mandarin orchards by using organic and biofertilization. Stem Cell, 4(2): 21-28.

Atom, A. (2013). Effect of inorganic and biofertilizers on growth, yield and quality of Sardar Guava (Psidium guajava L.). M.Sc.Thesis, College of Agriculture, Latur.

Balaganvi, S. and S.S. Kumathe (2004). Effect of different levels of drip irrigation and fertilizers application on growth, yield and quality parameters of Kagzi lime. Karnataka J. Agri. Sci., 17 (3): 626-628.

Barakat, M.R.; T.A. Yehia and B.M. Sayed (2012). Response of Newhall naval orange to bio-organic fertilization under newly reclaimed area conditions I: Vegetative growth and nutritional status. J. Hort. Sci. \& Ornamen. Plants, 4(1): 18-25.

Bhriguvanshi, S.R.; T. Adak; K. Kumar; V. Singh; A. Singh and V.K. Singh (2012). Soil moisture, organic carbon and micronutrients dynamics and their interrelationship in drip irrigated mango orchard. Journal of soil and Water Conservation, 11(4): 316-322.

Castle, W. (1983). Growth, yield and cold hardiness of seven year old 'Bearss' lemon on twenty seven rootstocks. Proc. Florida Sta. Hort. Soc. 96: 23-25.

Chou, G.J. (1966). A new method of measuring the leaf area of citrus trees. Acta. Hort. Sin., 5: 17-20.

Dahama, A.K. (1999). Organic farming for sustainable agriculture. Agro Botanic, Daryagun, New Delhi, India, pp. 258. 
El-Abd, A.A. (2005). Influence of fertilization and irrigation on Washington Navel orange orchards. Ph.D. Thesis, Fac. Agric., Tanta Univ., Egypt.

El-Haddad, M.E.; Y.Z. Ishac and M.I. Mostafa (1993). The role of biofertilizers in reducing agricultural costs, decreasing environmental pollution and raising crop yield. Arab Univ. J. Agric. Sci., 1: 147-195.

El-Haggar, S.M.; B.E. Ali; S.M. Ahmed and M.M. Hamdy (2004). Solubility of some natural rocks during composting. Proceedings of the 2nd Inter.Conf. Organic Agric.25-27 March, Nasr City, Cairo, Egypt, pp: 105-116.

El-Henaway, A.E.M. (2006). Effect of drip irrigation and soil mulching on some soil prosperities, yield and quality of Navel orange trees at North Delta. Ph.D. Thesis, Fac. Agric. Kafrelsheikh Univ. Egypt.

El-Khawaga, A.S. and M.F. Maklad (2013). Effect of combination between bio and chemical fertilization on vegetative growth, yield and quality of Valencia orange fruits. Hortscience Journal of Suez Canal University, 1: 269-279.

El-Koumy, H.M. (2012). Effect of irrigation regime and mulch on growth, yield and water use efficiency of pepper plants grown in the late summer season. Ph.D. Thesis, Fac. Agric. Kafrelsheikh Univ. Egypt.

El-Mohamedy, R.S.R. and M.A. Ahmed (2009). Effect of biofertilizers and humic acid on control of dry root rot disease and improvement yield quality of mandarin (Citrus reticulate Blanco). Res. J. Agric. \& Biol. Sci., 5(2): 127-137.

El-Sayed, S.A. and H.A. Ennab (2013). Effect of different levels of irrigation water and nitrogen fertilizer on vegetative growth, yield and fruit quality of Valencia orange trees. Minufiya J. Agric. Res., Vol. 38 No. 3(2): 761-773.

El-Wakeel H.F.; N. Mansour; M. Mubarak and E.A. Hassan (2013). The response of bearing Navel orange trees to some sources and rates of potassium fertilizers and silicate bacteria. J. Appl. Sci. Res., 9(11): 5780-5793.

Ennab, H.A. and S.A. El-Sayed (2014). Response of balady mandarin trees to deficit irrigation. J. Agric. Res. Kafrelsheikh Univ., 40(3): 616-629.

Fereres, E. and M.A Soriano (2007). Deficit irrigation for reducing agricultural water use. J. Exp. Botany, 58(2): 147-159.

Ferre, D.C. and C.G. Forshey (1988). Influence of pruning and urea spray on growth and fruiting of square bound Delicious apple trees. J. Amer. Soc. Hort. Sci., 113(5): 699-703.

Fiorella, S.P.D.; F. Intrigliolo; S. Consoli; A. Continella; and G. Roccuzzo (2015). Response of orange trees to deficit irrigation strategies: Effects on plant nutrition, yield, and fruit quality. J. Irrig. Drain Eng., 141: 1-9. 
García Petillo, M. and J.R. Castel (2004). The response of Valencia orange trees to irrigation in Uruguay. Spanish Journal of Agricultural Research, 2 (3): 429-443.

García-Tejero, I.; J.A. Jiménez-Bocanegra; G. Marténez; R. Romero; V.H. Durán-Zuazo and J.L. Muriel-Fernández (2010). Positive impact of regulated deficit irrigation on yield and fruit quality in a commercial citrus orchard [Citrus sinensis (L.) Osbeck, cv. salustiano]. Agricultural Water Management, 97: 614-622.

García-Tejero, I.; V.H. Durán-Zuazo and J.L. Muriel-Fernández (2011). Long-term impact of sustained-deficit irrigation on yield and fruit quality in sweet orange cv. Salustiana (SW Spain). Comunicata Scientiae, 2(2): 76-84.

Hegazi, A.H.; N.R. Samra; E.A. Hassan and A.M. Yasmin (2014). Effect of compost as organic fertilizer, natural rocks and some different biofertilizers on yield and quality of Flam seedless grapevines. J. Plant Production, Mansoura Univ., 5(10): 1625-1636.

Hussien, S.M.; E.A. Ismail; M.N.H. Ismail and T.A. Eid (2013). Effect of applying surface and bubbler irrigation systems on fruitful Washington Navel orange trees production. Egypt J. Agric. Res., 91(4): 1565-1580.

Ibe, R.B.; I.O. Lawal and A.A. Olaniyan (2011). Economic analysis of yields of citrus as influenced by organo-mineral fertilizer treatments in Ibadan, Southwest Nigeria. World J. Agric. Sci., 7(4): 425-429.

Ibrahim, A.M and M.F. Maklad (2014). Effect of partial replacement of mineral nitrogen fertilization by organic form on yield and leaf mineral content of Navel orange trees. J. Biol. Chem. Environ. Sci., 9(4): 671-681.

Kannaiyan, S. (2002). Biotechnology of bio-fertilizers. Alpha Science Inter. Ltd., P.O. Box 4067 Pang Bourne p 64.

Khalil, A.A.; M.W.A. Hassan and R.A. El-Wazzan (2000). Responses of mature navel orange trees to three methods of flood irrigation under North El-Tahreer conditions. Bull. Fac. Agric., Cairo Univ., 51(3): 349-364.

Kumar, D; V. Pandey; K. Anjaneyulu and V. Nath (2008). Relationship of trunk cross-sectional area with fruit yield, quality and leaf nutrients status in Allahabad Safeda guava (Psidium guajava). Indian J. Agric. Sci. 78: 337-39.

Luo, P. ; X. Han ; Y. Wang; M. Han; H. Shi; N. Liu and H. Bai (2015). Influence of long-term fertilization on soil microbial biomass, dehydrogenase activity, and bacterial and fungal community structure in a brown soil of northeast China. Ann Microbiol, 65(1): 533-542.

Mansour, A.E.M. and E.A. Shaaban (2007). Effect of different sources of mineral $\mathbf{N}$ applied with organic and bio fertilizers on fruiting of Washington Navel orange trees. J. Appl. Sci. Res., 3(8): 764-769.

Michael, A.M. (1978). Irrigation-theory and practice Vikus publishing House, PV Ltd. New Delhi, India. 
Ministry of Agriculture and Land Reclamation (2014). Bulletin of the agricultural statistics, part (2) Summer \& Nile crops, 2012/2013, Cairo, Egypt.

Mohamed, N.M. (2008). Reducing agrochemical residues in grapes by using different sources from bio and organic fertilizers. Ph.D. Thesis. Institute. of Environ. Stud., and Res., Ain Shams Univ.

Morgan, K.T.; T.A. Wheaton; W.S. Castle and L.R. Parsons (2009). Response of young and maturing citrus trees grown on a sandy soil to irrigation scheduling, nitrogen fertilizer rate, and nitrogen application method. HortScience, 44(1):145-150.

Nijjar, G.S. (1985). Nutrition of fruit trees. Kalyani Publishers, New Delhi. India, pp 10-52.

Omar, E.H. (1998). Studies on the effect of mid to late season drought and potassium fertilization on water relations and yield of sugar beet crop at North Delta. Ph.D. Thesis, Fac. Agric. Kafrelsheikh Univ. Egypt.

Page, A.L.; R.H. Miller and D.R. Keeney (1982). Methods of soil analysis part 2: chemical and microbiological properties second edition. Agronomy 920 Am. Soc. Agron. Inc. Soil Sci. Soc. Am. Inc. Pub. Madison, Wisconsin, USA.

Panigrahi, P.; R.K. Sharma; M. Hasan and S.S. Parihar (2014). Deficit irrigation scheduling and yield prediction of 'Kinnow' mandarin (Citrus reticulate Blanco) in a semiarid region. Agricultural Water Management, 140: 48-60.

Pascual, I.; M.C. Antolín; C. García; A. Polo and M. Sanchez-Díaz (2007). Effect of water deficit on microbial characteristics in soil amended with sewage sludge or inorganic fertilizer under laboratory conditions. Bioresource Technology, 98: 29-37.

Pérez-Pérez, J.G.; P. Romero; J.M. Navarro and P. Botía (2008). Response of sweet orange cv 'lane late' to deficit irrigation strategy in two rootstocks II: flowering, fruit growth, yield and fruit quality. Irrig. Sci., 26: 519-529.

Saleh, M.M.M. (2002). Biological control of some soil disease on corn. M.Sc. Fac. Agric. Kafr El-sheikh. Tanta University, PP 27.

Shiralipour, A.; D. McConnell and W. Smith (1992). Physical and chemical properties of soils as affected by municipal solid waste compost application. Biomass and Bioenergy, 3: 261-266.

Shirgure, P.S.; A.K. Srivastava and A.D. Huchche (2014). Water requirement in growth stages and effects of deficit irrigation on fruit productivity of drip irrigated Nagpur mandarin (Citrus reticulate Blanco). Indian Journal of Agricultural Sciences, 84(3): 317-322.

Shukla, S.K.; T. Adak; A. Singha; K. Kumar, V. K. Singh and A. Singh (2014). Response of guava trees (Psidium guajava) to soil applications of mineral and organic fertilizers and biofertilizers under conditions of low fertile soil. Journal of Horticultural Research, 22(2): 105-114. 
Singha, A.; T. Adak; K. Kumar; S.K. Shukla and V.K. Singh (2014). Effect of integrated nutrient management on dehydrogenase activity, soil organic carbon and soil moisture variability in a mango orchard ecosystem. The Journal of Animal \& Plant Sciences, 24(3): 843-849.

Snedecor, G.W. and W.G. Cochran (1990). Statistical methods. $7^{\text {th }}$ Ed. lowa State Univ. Press. Ames., lowa, USA, p. 593.

Subba-Rao, N.S. (1984). Biofertilizers in Agriculture. Oxford, IBH Company. New Delhi, pp 10-20.

Tabatabai M.A. (1982). Soil enzymes, Dehydrogenases. In: Methods of Soil Analysis. Part 2. Chemical and Microbiolgical Properties (Eds R.H. Miller and D.R. Keeney). Agron. Monography, 9, ASA and SSSA, Madison, WI.

Trinchera, A.; B. Torrisi; M. Allegra; S. Rinaldi; E. Rea; F. Intrigliolo and G. Roccuzzo (2015). Effect of organic fertilization on soil organic matter and root morophology and density of orange trees. Acta Hort., 1065: 1807-1814.

Wang, J.; S. Kang; F. Li; F. Zhange; Z. Li and J. Zhang (2008). Effects of alternate partial root-zone irrigation on soil microorganism and maize growth. Plant Soil, 302: 45-52.

Wassel, A.H.; F.F. Ahmed; MA. Ragab and M.M. Ragab (2007). Response of Balady mandarin trees to drip irrigation and nitrogen fertigation. I. Effect of nitrogen fertigation and drip irrigation on the vegetative growth and the yield of Balady mandarin trees (Citrus reticulate). African Crop Sci. Conference Proceeding, 8: 503-511.

Wassel, A.M.; M.A. El- Sayed; A.Y. Mohamed and E.A.M. Hassan (2015). Effect of using plant compost enriched with Spirulina platensis algae as a partial replacement of inorganic $\mathbf{N}$ fertilization on fruiting of Ewaise mangoes. World Rural Observations, 7(3): 102109.

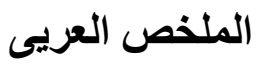

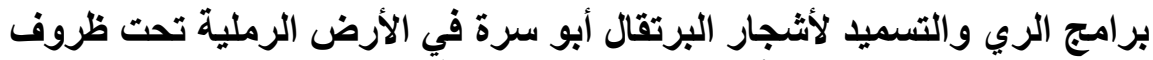

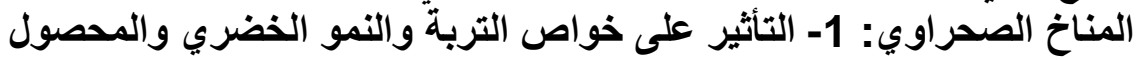

$$
\begin{aligned}
& \text { محمد عبده زيان(1) رمضان أبو سريع سيد(2) على رمضان الشريف(1) }
\end{aligned}
$$

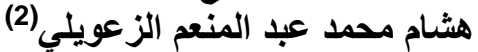

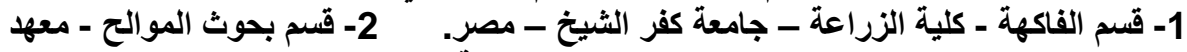

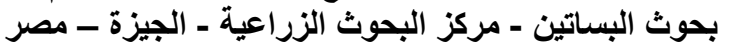

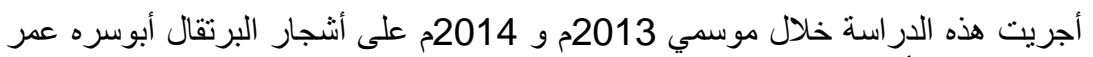

$$
\begin{aligned}
& 7 \text { سنو ات مطعومه على أصل الفولكاماريانا بمزر عة تجة تجارية قرب مدينة النوبارية ــ محافظة البحيرة ـ }
\end{aligned}
$$


مصر لتقييم تأثثر أنواع مختلفة من الأسمدة بإستخدام الأسمدة العضوية و الحيوية جزئياً بديلاً للأسمدة

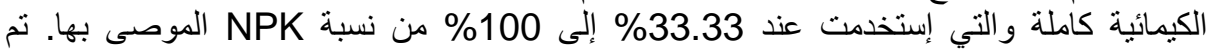

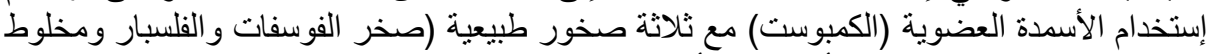

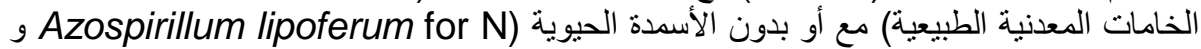
(Bacillus circulans for K, Bacillus megaterium for P

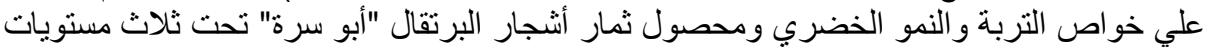

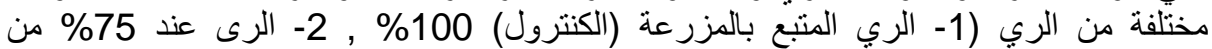
الكنترول , 3- الرى عند 75\% من الكنترول) في الأرض الرئرون الرملية تحت نظام الري بالتنقيط. أظهرت

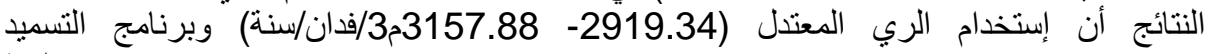

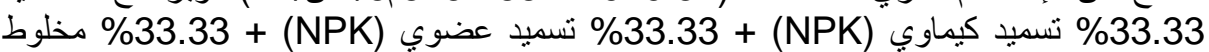

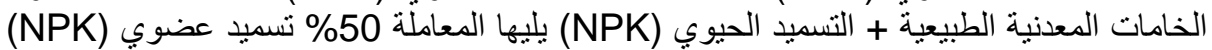

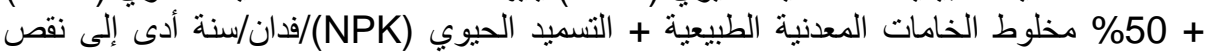

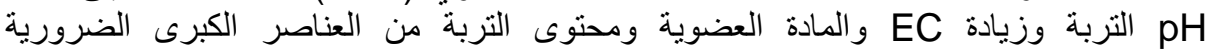

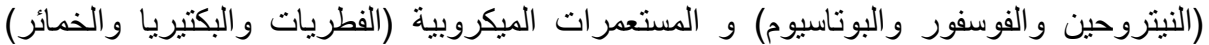

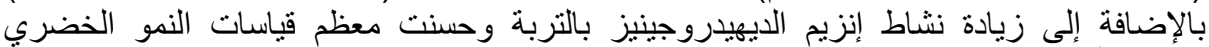

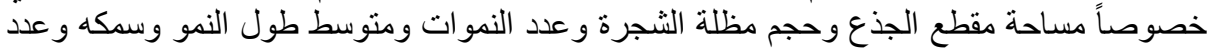

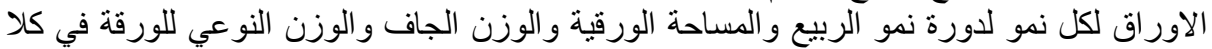

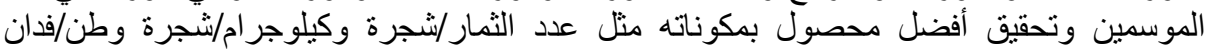

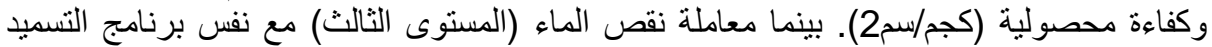

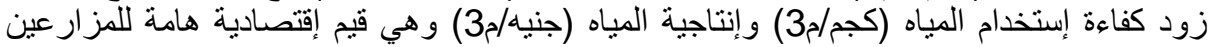

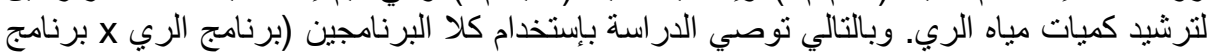

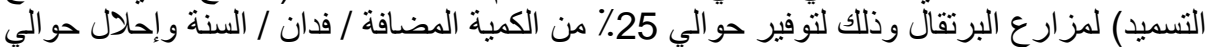

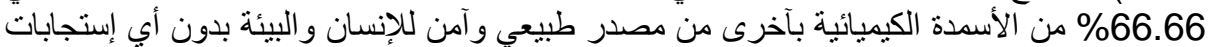

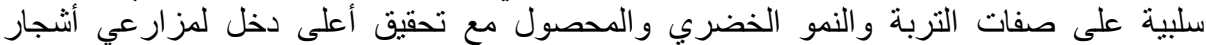
البرتقال "أبو سره" تحت ظروف هذه الدر اسة. 